Article

\title{
Design of New Polyaspartamide Copolymers for siRNA Delivery in Antiasthmatic Therapy
}

\author{
Emanuela Fabiola Craparo ${ }^{1}$, Salvatore Emanuele Drago ${ }^{1}$, Nicolò Mauro ${ }^{1,2}$, \\ Gaetano Giammona ${ }^{1}$ and Gennara Cavallaro ${ }^{1, *}$ \\ 1 Lab of Biocompatible Polymers, Department of Biological, Chemical and Pharmaceutical Sciences and \\ Technologies (STEBICEF), University of Palermo, via Archirafi 32, 90123 Palermo, Italy; \\ emanuela.craparo@unipa.it (E.F.C.); salvatoreemanuele.drago@unipa.it (S.E.D.); \\ nicolo.mauro@unipa.it (N.M.); gaetano.giammona@unipa.it (G.G.) \\ 2 Fondazione Umberto Veronesi, Piazza Velasca 5, 20122 Milano, Italy \\ * Correspondence: gennara.cavallaro@unipa.it; Tel.: +39-091-2389-1931
}

Received: 3 December 2019; Accepted: 18 January 2020; Published: 22 January 2020

\begin{abstract}
Here, a novel protonable copolymer was realized for the production of polyplexes with a siRNA (inhibitor of STAT6 expression in asthma), with the aim of a pulmonary administration. The polycation was synthesized by derivatization of $\alpha, \beta$-poly $(\mathrm{N}-2$-hydroxyethyl) $\mathrm{D}, \mathrm{L}$-aspartamide (PHEA) with 1,2-Bis(3-aminopropylamino)ethane (bAPAE) in proper conditions to obtain a PHEA-g-bAPAE graft copolymer with a derivatization degree in amine (DD $\mathrm{bAPAE}_{\mathrm{o}}$ ) equal to $35 \mathrm{~mol} \%$. The copolymer showed a proper buffering behavior, i.e., ranging between pH 5 and 7.4, to potentially give the endosomal escape of the obtained polycations. In effect, an in vitro experiment demonstrated the effect on biological membranes of the copolymer on bronchial epithelial cells (16-HBE) strongly dependent on the $\mathrm{pH}$ of the medium, i.e., higher at $\mathrm{pH}$ 5. bAPAE-based copolymers were further obtained with an increasing pegylation degree, i.e., equal to $1.9,2.7$, and $4.4 \mathrm{~mol} \%$, respectively. All the obtained copolymers were able to complex siRNA at a N/P ratio that decreases as the pegylation degree increases. At the same time, the tendency of polyplexes to aggregate and the capability to interact with mucin also decreases as the pegylation in the copolymer increases. Gene silencing experiments on 16-HBE showed that these copolymers have a significant role in improving the intracellular transport of naked siRNA, where the presence of PEG does not seem to hinder the cellular uptake of polyplexes. The latter obtained at polymer/siRNA weight ratio (R) equal to 10 with PHEA-g-PEG(C)-g-bAPAE also seems to be not susceptible to the presence of mucin, avoiding the polyanionic exchange of complexed siRNA, thus showing adequate behavior to be used as an effective vector for siRNA.
\end{abstract}

Keywords: siRNA; STAT6; polyaspartamide; pegylation; polyamine; polyplexes; asthma

\section{Introduction}

Although it is not a deadly disease, asthma can be highly debilitating, resulting in irreversible lung damage [1]. The international guidelines of the Global Initiative for Asthma (GINA) define asthma as a pathological state characterized by chronic inflammation of the airways and reversible limitation of air flow. However, persistent lung inflammation could cause airway obstruction or hyper-reactivity, so that when the treatment is inadequate, airway re-modelling can occur and the obstruction becomes irreversible [1]. The inflammatory cascade in allergic asthma, which involves the lung infiltration of eosinophils, T lymphocytes, mast cells, and other inflammatory cells, is schematically summarized in Figure 1. 


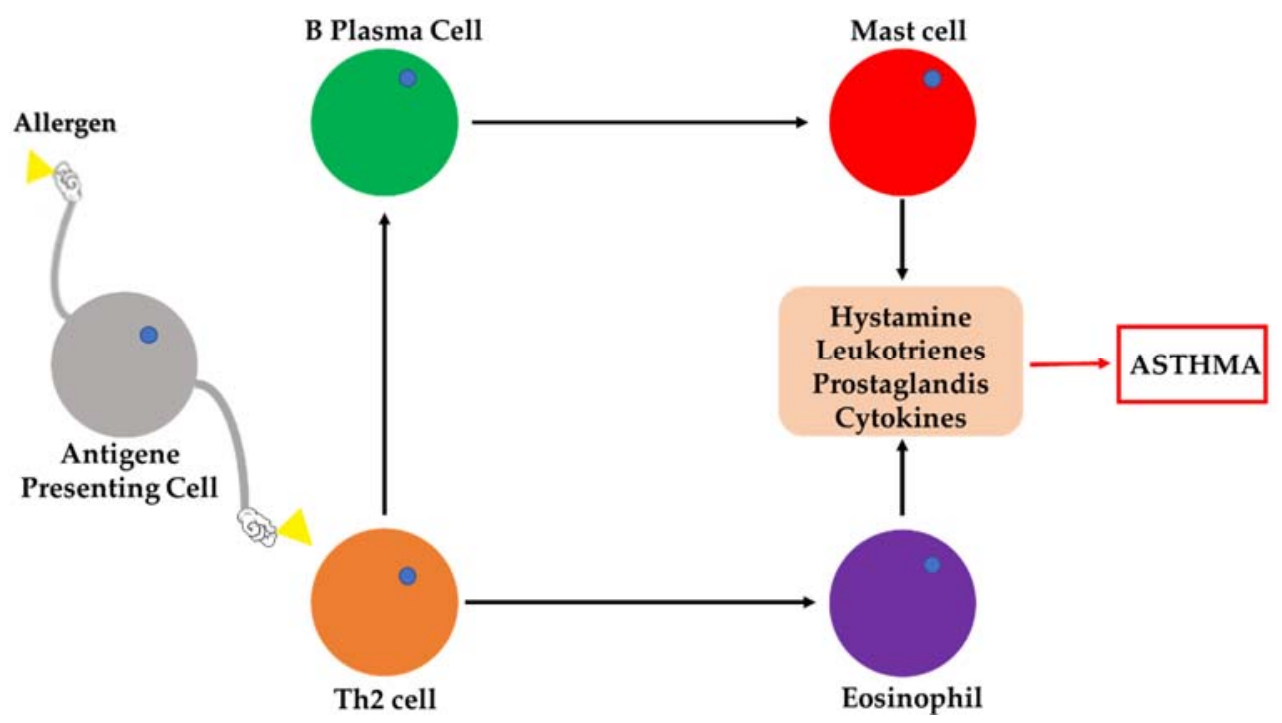

Figure 1. Schematic representation of the inflammatory cascade in allergic asthma.

The conventional drug therapy includes both bronchodilators (such as $\beta-2$ adrenergic agonists and anticholinergics) to control symptoms, and corticosteroids to reduce the inflammatory process. Inhaled corticosteroids represent an effective first-line treatment in mild asthma, but they have therapeutic limitations in patients with moderate to severe asthma due to several side effects, although the local administration allows to significantly reduce the administered dose [2,3].

The conventional therapies, therefore, are often associated with a series of limitations that have pushed the research towards the identification of new biological targets for treatment of the pathology. It has been seen that in individuals suffering from asthma there is overexpression of numerous genes and proteins, such as Signal Transducer and Activator of Transcription 6 (STAT6) [4], Plasminogen Activator Inhibitor-1 (PAI-1) [5], and Spleen Tyrosine Kinase (Syk) [6]. In particular, STAT6 regulates the T helper type $2\left(\mathrm{Th}_{2}\right)$ immune response, PAI-1 is associated with asthma severity because of its role in airway remodeling, while Syk is implicated as central immune modulator promoting allergic airway inflammation; thus, their inhibition could be an effective therapeutic approach in asthma.

For these reasons, an alternative therapeutic approach of pathological states caused by an increase in the expression of some genes, as in the case of asthma, could be gene therapy, through the administration of small interference RNA (siRNA). These consists of small double-stranded RNA fragments capable of triggering the degradation of a specific mRNA [7] and therefore ultimately capable of blocking the synthesis of certain proteins. Recently, the true efficacy of siRNA directed against particular targets, such as STAT6, PAI-1, and Syk for the treatment of asthma was demonstrated through appropriate in vitro and in vivo studies [4-6].

However, despite the potential of this genetic material, it is well known that it cannot be administered as it is, also if given directly in situ, but requires the use of particular vectors capable of conveying it into the body $[7,8]$. The use of siRNA as therapeutic agents necessarily requires the use of a vector, which by neutralizing the negative charge may allow them to enter cells, as well as increasing their stability against enzymatic degradation by nucleases. Among gene vectors, polymeric materials have many advantages, as they can carry large quantities of genetic material and can be chemically derivatized to obtain systems specifically oriented towards particular target tissues [9,10]. The cationic character of such polymers, necessary for the establishment of interactions with negative-charged gene material to form polyplexes, is conferred by protonable amino groups at physiological or neutral $\mathrm{pH}$. However, other peculiarities are often required of the polymeric material, therefore a starting material easily modifiable by simple chemical reactions is highly sought after.

Considering the above, the aim of the present experimental work was to realize a novel protonable polymeric derivative able to form a stable electrostatic complex with the chosen siRNA, and to delivery it, 
through the inhalation route, at the bronchial level for the realization of an innovative formulation for the management of asthma. We have chosen to work with the $\alpha, \beta$-poly-N-2-hydroxyethyl-DL-aspartamide (PHEA) as the starting polymeric material [11], being a highly soluble in water, biocompatible, non-immunogenic, non-antigenic polymer, already used for the development of highly performing polymeric gene vectors [12,13], as well as many other drug carriers [14-17]. Moreover, as molecule to conjugate to the PHEA backbone, in order to give the cationic behavior, we have chosen an oligoamine, the 1,2-Bis(3-aminopropylamino)ethane (bAPAE), that could give a good complexing capability, an improvement of cell internalization, associated with a good cytocompatibility [18]. As genetic material has been chosen a therapeutic siRNA able to reduce the expression of STAT6, that is one of the most important transcription factors that regulate the production of Th2 cytokines and effector functions mediated by Th2 cytokines [19-22], which seems to have a major role in the mechanism that initiates an asthmatic attack.

In addition to complexing ability to the genetic material, the copolymer forming the siRNA complex should possess additional characteristics, after administration by the pulmonary route, to further diffuse trough the mucus layer present at the airway level, until reach the bronchial epithelial cells. The latter are the main target for the siRNA delivery. To confer penetrating mucus capacity to the system it is possible to increase the superficial hydrophilicity of the system, thus reducing interactions with the protein chains of the mucin; for this reason, the PHEA backbone was also conjugated with a proper amount of poly(ethyleneglycole) (PEG) [23,24]. Therefore the potential of this new polyaspartamide copolymers as material able to complex and delivery a specific siRNA for antiasthmatic therapy was tested.

\section{Materials and Methods}

\subsection{Materials}

Triethylamine (TEA), Bis(4-nitrophenyl)carbonate (BNPC), anhydrous $N, N^{\prime}$-dimethylformamide (a-DMF), 1,2-Bis(3-aminopropylamino)ethane (bAPAE), O-(2-Aminoethyl)-O'-methyl poly(ethylene glycol) $2000\left(\mathrm{H}_{2} \mathrm{~N}-\mathrm{PEG}_{2000}\right)(0.4 \mathrm{mmol} \mathrm{NH} / \mathrm{g})$, disuccinimidylcarbonate (DSC), dichloromethane, aceton, diethylether, 2,4,6-Trinitrobenzenesulfonic acid (TNBS), agarose, ethidium bromide, mucine from porcin stomach were purchased from Sigma-Aldrich (Milan, Italy). All used reagents were of analytic grade.

Duplexed siRNA were purchased from Biomers.net (Ulm, Germany). The gene target sequences $\left(5^{\prime} \rightarrow 3^{\prime}\right)$ are: CAGUUCCGCCACUUGCCAA (sense), UUGGCAAUGGCGGAACUG (antisense).

$\alpha, \beta$-poly(N-2-hydroxyethyl)-D,L-aspartamide (PHEA) was synthetized via polysuccinimide (PSI) reaction with ethanolamine in DMF solution, and purified according to a previously reported procedure [11].

${ }^{1} \mathrm{H}-\mathrm{NMR}\left(300 \mathrm{MHz}, \mathrm{D}_{2} \mathrm{O}, 25^{\circ} \mathrm{C}\right.$, TMS): $\delta 2.71$ ( $\left.\mathrm{m}, 2 \mathrm{H}_{\text {PHEA }},-\mathrm{COCHCH}_{2} \mathrm{CONH}-\right), \delta 3.24\left(\mathrm{~m}, 2 \mathrm{H}_{\text {PHEA }}\right.$, $\left.-\mathrm{NHCH}_{2} \mathrm{CH}_{2} \mathrm{O}-\right), \delta 3.55\left(\mathrm{~m}, 2 \mathrm{H}_{\mathrm{PHEA}},-\mathrm{NHCH}_{2} \mathrm{CH}_{2} \mathrm{OH}\right), \delta 4.59\left[\mathrm{~m}, 1 \mathrm{H}_{\mathrm{PHEA}},-\mathrm{NHCH}(\mathrm{CO}) \mathrm{CH}_{2}-\right]$.

\subsection{Copolymer Synthesis}

2.2.1. General Procedure for the Derivatization and Characterization of $\alpha, \beta$-poly(N-2-hydroxyethyl)D,L-aspartamide with 1,2-Bis(3-aminopropylamino)ethane (PHEA-g-bAPAE)

Derivatization of PHEA with 1,2-Bis(3-aminopropylamino)ethane (bAPAE) was carried out by using Bis(4-nitrophenyl) carbonate (BNPC) as coupling agent. Two hundred milligrams of PHEA (1.26 mmol of repeating units (RU)) were dissolved in $4 \mathrm{~mL}$ of a-DMF; after complete solubilization, $230 \mathrm{mg}$ of solid BNPC was added. The solution was stirred at $40{ }^{\circ} \mathrm{C}$ for $4 \mathrm{~h}$. Simultaneously, $922.71 \mu \mathrm{L}$ of bAPAE was dissolved in $7 \mathrm{~mL}$ of a-DMF. After activation time, the resulting polymeric solution was added dropwise and slowly to bAPAE solution. The reaction was carried out under and continuous stirring at $25{ }^{\circ} \mathrm{C}$ for $20 \mathrm{~h}$. The amounts of each reagent were properly determined accordingly to 
$\mathrm{R}_{1}=(\mathrm{mmol}$ of $\mathrm{BNPC} / \mathrm{mmol}$ of functionalizable RU on PHEA $)=0.6$ and $\mathrm{R}_{2}=(\mathrm{mmol}$ of $\mathrm{bAPAE} / \mathrm{mmol}$ of functionalizable RU on PHEA) $=4$.

After this time, the polymer was isolated from reaction mixture by precipitation in mixture $2: 1 \mathrm{v} / \mathrm{v}$ diethyl ether/dichloromethane and the supernatant was removed by centrifugation at $4{ }^{\circ} \mathrm{C}$ for $8 \mathrm{~min}$, at $9800 \mathrm{rpm}$. The obtained solid product was washed with acetone, until the $\mathrm{pH}$ of a mixture between the washing acetone with water (vol:vol 1:1) was neutral. Then, the obtained product was dried under vacuum. The solid residue was dissolved in double distilled water and then the solution was purified by dialysis (SpectraPor Dialysis Tubing, at MWCO $25 \mathrm{kDa}$ ), for two days against basic water $(\mathrm{NaOH})$ and for other three days against bidistilled water, subsequently the solution was freeze-dried and stored for further characterization. PHEA-g-bAPAE graft copolymer was obtained with a yield of $80 \mathrm{wt} \%$ based on the starting PHEA.

${ }^{1} \mathrm{H}-\mathrm{NMR} \quad\left(300 \mathrm{MHz}, \quad \mathrm{D}_{2} \mathrm{O} \quad \mathrm{pD} \quad 5, \quad 25 \quad{ }^{\circ} \mathrm{C}, \quad \mathrm{TMS}\right): \quad \delta \quad 1.70-2.20 \quad\left(\mathrm{~m}, \quad 4 \mathrm{H}_{\mathrm{bAPAE}}\right.$, $\left.-\mathrm{NHCH}_{2} \mathrm{CH}_{2} \mathrm{CH}_{2} \mathrm{NHCH}_{2} \mathrm{CH}_{2} \mathrm{NHCH}_{2} \mathrm{CH}_{2} \mathrm{CH}_{2} \mathrm{NH}-\right)$, $\delta 2.73$ (m, 2H $\left.\mathrm{H}_{\mathrm{PHEA}},-\mathrm{COCHCH}_{2} \mathrm{CONH}-\right)$, $\delta 3,12\left(\mathrm{~m}, 8 \mathrm{H}_{\mathrm{bAPAE}},-\mathrm{NHCH}_{2} \mathrm{CH}_{2} \mathrm{CH}_{2} \mathrm{NHCH}_{2} \mathrm{CH}_{2} \mathrm{NHCH}_{2} \mathrm{CH}_{2} \mathrm{CH}_{2} \mathrm{NH}_{2}\right), \delta 3.23\left(\mathrm{~m}, 2 \mathrm{H}_{\mathrm{PHEA}}\right.$, $\left.-\mathrm{NHCH}_{2} \mathrm{CH}_{2} \mathrm{O}-\right)$ ) 3,38 (m, $\left.4 \mathrm{H}_{\mathrm{bAPAE}},-\mathrm{CONHCH}_{2} \mathrm{CH}_{2}-,-\mathrm{CH}_{2} \mathrm{CH}_{2} \mathrm{CH}_{2} \mathrm{NH}_{2}\right), \delta 3.54\left(\mathrm{~m}, 2 \mathrm{H}_{\text {PHEA }}\right.$, $\left.-\mathrm{NHCH}_{2} \mathrm{CH}_{2} \mathrm{OH}\right), \delta 3.60\left(\mathrm{~m}, 4 \mathrm{H}_{\mathrm{PEG}},-\left[\mathrm{OCH}_{2} \mathrm{CH}_{2} \mathrm{O}\right]_{44}-\right), \delta 4.02\left(\mathrm{~m}, 2 \mathrm{H}_{\mathrm{PHEA}},-\mathrm{NHCH}_{2} \mathrm{CH}_{2} \mathrm{OCO}-\right), \delta$ $4.62\left(\mathrm{~m}, 1 \mathrm{H}_{\mathrm{PHEA}},-\mathrm{NHCH}(\mathrm{CO}) \mathrm{CH}_{2}-\right)$. The content of amine was also determined by TNBS assay [12].

2.2.2. General Procedure for the Derivatization and Characterization of PHEA with methoxy polyethylene glycol amine $\left(\mathrm{H}_{3} \mathrm{CO}-\mathrm{PEG}-\mathrm{NH}_{2}\right)$

Derivatization of PHEA with different amount of $\mathrm{H}_{3} \mathrm{CO}-\mathrm{PEG}-\mathrm{NH}_{2}$, was carried out by using $\mathrm{N}, \mathrm{N}^{\prime}$-disuccinimidyl carbonate (DSC) as coupling agent [23]. Five hundred milligrams of PHEA (6.32 mmol of RU) was dissolved in $10 \mathrm{~mL}$ of a-DMF at $40{ }^{\circ} \mathrm{C}$ and then a proper amount of triethylamine (TEA), as catalyst, and DSC were added; subsequently, the reaction mixture was left at $40^{\circ} \mathrm{C}$ for $4 \mathrm{~h}$.

After the activation time, the latter dispersion of DSC-activated PHEA was added drop-wise to increasing volumes of $\mathrm{H}_{3} \mathrm{CO}-\mathrm{PEG}-\mathrm{NH}_{2}$ dispersions in a-DMF, at a concentration of $50 \mathrm{mg} / \mathrm{mL}$. Then, the obtained mixture reactions were left at $25^{\circ} \mathrm{C}$ for $18 \mathrm{~h}$. The amounts of TEA, DSC and PEG were added according to the following moles ratios, as reported in Table 1.

Table 1. Molar ratio and $\mathrm{mL}$ of poly(ethyleneglycole) (PEG) solution (50 mg/mL) used for synthesis.

\begin{tabular}{lccccc}
\hline Copolymers & $\mathbf{R}_{\mathbf{3}}$ & $\mathbf{R}_{\mathbf{4}}$ & $\mathbf{R}_{\mathbf{5}}$ & $\begin{array}{c}\text { PEG Solution } \\
(\mathbf{m L})\end{array}$ & $\begin{array}{c}\text { PEG Weight } \\
\text { Amount (mg) }\end{array}$ \\
\hline PHEA-g-PEG(A) & 0.03 & 0.04 & 1 & 4 & 200 \\
\hline PHEA-g-PEG(B) & 0.075 & 0.1 & 1 & 9.5 & 475 \\
\hline PHEA-g-PEG(C) & 0.12 & 0.16 & 1 & 15 & 750 \\
\hline $\begin{array}{l}\mathrm{R}_{3}=(\text { mmol of aminoPEG/mmol of functionalizable RU on PHEA) } \\
\mathrm{R}_{4}=(\text { mmol of DSC/mmol of functionalizable RU on PHEA) } \\
\mathrm{R}_{5}=(\text { mmol of TEA/mmol of DSC) }\end{array}$ \\
\hline
\end{tabular}

After this time, each polymer was isolated from reaction mixture by precipitation diethyl ether and the supernatant was removed by centrifugation at $4{ }^{\circ} \mathrm{C}$ for $8 \mathrm{~min}$, at $9800 \mathrm{rpm}$. The obtained solid product was washed with acetone one time and then, the obtained product was dried under vacuum. The solid residue was dissolved in double distilled water and then the solution was purified by dialysis (SpectraPor Dialysis Tubing, at MWCO $25 \mathrm{kDa}$ ), subsequently freeze-dried and stored for further characterization. PHEA-g-PEG graft copolymers were obtained with a yield of $220 \mathrm{wt} \%$ based on the starting PHEA. Three different PHEA- $g$-PEG graft copolymers in terms of PEG grafted on the PHEA backbone, that were named PHEA- $g$-PEG(A) and PHEA- $g$-PEG(B) and PHEA- $g$-PEG(C).

${ }^{1} \mathrm{H}-\mathrm{NMR}\left(300 \mathrm{MHz}, \mathrm{D}_{2} \mathrm{O}, 25{ }^{\circ} \mathrm{C}\right.$, TMS): $\delta 2.71$ (m, 2 $\left.\mathrm{H}_{\text {PHEA }},-\mathrm{COCHCH}_{2} \mathrm{CONH}-\right), \delta 3.24(\mathrm{~m}$, $\left.2 \mathrm{H}_{\mathrm{PHEA}},-\mathrm{NHCH}_{2} \mathrm{CH}_{2} \mathrm{O}-\right), \delta 3.55\left(\mathrm{~m}, 2 \mathrm{H}_{\mathrm{PHEA}},-\mathrm{NHCH}_{2} \mathrm{CH}_{2} \mathrm{OH}\right), \delta 3.60\left(\mathrm{~m}, 4 \mathrm{H}_{\mathrm{PEG}},-\left[\mathrm{OCH}_{2} \mathrm{CH}_{2} \mathrm{O}_{44}-\right)\right.$, $\delta 4.59\left(\mathrm{~m}, 1 \mathrm{H}_{\text {PHEA }},-\mathrm{NHCH}(\mathrm{CO}) \mathrm{CH}_{2}-\right)$. 


\subsubsection{General Procedure for the Derivatization and Characterization of PHEA-g-PEG with bAPAE}

Derivatization of PHEA- $g$-PEG with bAPAE was carried out by using BNPC as coupling agent. $232 \mathrm{mg}$ of PHEA-g-PEG(A), $278 \mathrm{mg}$ of PHEA-g-PEG(B), or $329 \mathrm{mg}$ of PHEA-g-PEG(C) (corresponding to $1.26 \mathrm{mmol}$ of functionalizable RU) was dissolved in $4 \mathrm{~mL}$ of a-DMF; after complete solubilization, $230 \mathrm{mg}$ of solid BNPC was added. The solution was stirred at $40{ }^{\circ} \mathrm{C}$ for $4 \mathrm{~h}$. Simultaneously, $922.71 \mu \mathrm{L}$ of bAPAE was dissolved in $7 \mathrm{~mL}$ of a-DMF. The reagents were added accordingly to $\mathrm{R}_{1}=(\mathrm{mmol}$ of BNPC $/ \mathrm{mmol}$ of functionalizable RU on PHEAPEG $)=0.6$ and $R_{7}=(\mathrm{mmol}$ of $\mathrm{bAPAE} / \mathrm{mmol}$ of functionalizable RU on PHEAPEG) $=4$.

After activation time, the resulting polymeric solution was added dropwise and slowly to bAPAE solution. The reaction was carried out under continuous stirring at $25{ }^{\circ} \mathrm{C}$ for $20 \mathrm{~h}$. After this time, the polymer was isolated from reaction mixture by precipitation in mixture 2:1 $v / v$ diethyl ether/dichloromethane and the supernatant was removed by centrifugation at $4{ }^{\circ} \mathrm{C}$ for $8 \mathrm{~min}$, at $9800 \mathrm{rpm}$. The obtained solid product was washed with acetone, until the $\mathrm{pH}$ of the washing surnatant was neutral. Then, the obtained product was dried under vacuum. The solid residue was dissolved in double distilled water and then the solution was purified by dialysis (SpectraPor Dialysis Tubing, at MWCO $25 \mathrm{kDa}$ ), subsequently the solution was freeze-dried and stored for further characterization. PHEA-g-PEG- $g$-bAPAE graft copolymers were obtained with a yield of $80 \mathrm{wt} \%$ based on the starting PHEA-g-PEG.

${ }^{1} \mathrm{H}-\mathrm{NMR} \quad\left(300 \mathrm{MHz}, \quad \mathrm{D}_{2} \mathrm{O} \quad \mathrm{pD} \quad 5, \quad 25 \quad{ }^{\circ} \mathrm{C}, \quad \mathrm{TMS}\right): \delta \quad 1.70-2.20 \quad\left(\mathrm{~m}, \quad 4 \mathrm{H}_{\mathrm{bAPAE}}\right.$, $-\mathrm{NHCH}_{2} \mathrm{CH}_{2} \mathrm{CH}_{2} \mathrm{NHCH}_{2} \mathrm{CH}_{2} \mathrm{NHCH}_{2} \mathrm{CH}_{2} \mathrm{CH}_{2} \mathrm{NH}-$ ), $\delta 2.73$ (m, 2H $\mathrm{H}_{\mathrm{PHEA}},-\mathrm{COCHCH}_{2} \mathrm{CONH}-$ ), $\delta 3.12\left(\mathrm{~m}, 8 \mathrm{H}_{\mathrm{bAPAE}},-\mathrm{NHCH}_{2} \mathrm{CH}_{2} \mathrm{CH}_{2} \mathrm{NHCH}_{2} \mathrm{CH}_{2} \mathrm{NHCH}_{2} \mathrm{CH}_{2} \mathrm{CH}_{2} \mathrm{NH}_{2}\right), \delta 3.23$ (m, $2 \mathrm{H}_{\text {PHEA }}$, $\left.-\mathrm{NHCH}_{2} \mathrm{CH}_{2} \mathrm{O}-\right), 3,38\left(\mathrm{~m}, 4 \mathrm{H}_{\text {bAPAE}},-\mathrm{CONHCH}_{2} \mathrm{CH}_{2}-,-\mathrm{CH}_{2} \mathrm{CH}_{2} \mathrm{CH}_{2} \mathrm{NH}_{2}\right), \delta 3.54\left(\mathrm{~m}, 2 \mathrm{H}_{\text {PHEA }}\right.$, $\left.-\mathrm{NHCH}_{2} \mathrm{CH}_{2} \mathrm{OH}\right), \delta 3.60\left(\mathrm{~m}, 4 \mathrm{H}_{\mathrm{PEG}},-\left[\mathrm{OCH}_{2} \mathrm{CH}_{2} \mathrm{O}\right]_{44}-\right)$, $\delta 4.02\left(\mathrm{~m}, 2 \mathrm{H}_{\mathrm{PHEA}},-\mathrm{NHCH}_{2} \mathrm{CH}_{2} \mathrm{OCO}-\right)$, $\delta 4.62\left(\mathrm{~m}, 1 \mathrm{H}_{\text {PHEA }},-\mathrm{NHCH}(\mathrm{CO}) \mathrm{CH}_{2}-\right)$.

\subsection{Determination of the Amine Content}

The content of amine-terminated side chains was also determined by TNBS assay. A stock solution of PHEA- $g$-bAPAE or PHEA- $g$-PEG(A)- $g$-bAPAE or PHEA- $g$-PEG(B)- $g$-bAPAE or PHEA-g-PEG(C)- $g$-bAPAE $(5 \mathrm{mg} / \mathrm{mL})$ was prepared in a borate buffer $\left(0.1 \mathrm{M} \mathrm{Na}_{2} \mathrm{~B}_{4} \mathrm{O}_{7} \cdot \mathrm{H}_{2} \mathrm{O}, \mathrm{pH}\right.$ 9.3). An aliquot of this solution $(50 \mu \mathrm{L})$ was added to a cuvette containing $900 \mu \mathrm{L}$ of borate buffer and $50 \mu \mathrm{L}$ of $0.03 \mathrm{M}$ TNBSA solution. After $120 \mathrm{~min}$ incubation, absorbance at $\lambda 500 \mathrm{~nm}$ was measured and compared with that estimated for the reaction of $\mathrm{H}_{2} \mathrm{~N}-\mathrm{PEG}-\mathrm{OCH}_{3}\left(-\mathrm{NH}_{2}\right.$ in the range between 0.01 and $0.001 \mathrm{mmol} / \mathrm{mL}$ ) with TNBSA.

\subsection{Size Exclusion Chromatography}

Weight-average molecular weight $\left(\overline{\mathrm{M}}_{\mathrm{w}}\right)$, polydispersity index $\left(\overline{\mathrm{M}}_{\mathrm{w}} / \overline{\mathrm{M}}_{\mathrm{n}}\right)$, of each copolymer was determined by a size exclusion chromatography (SEC) analysis, performed using Tosho Bioscience TSK-Gel G4000 PWXL and G3000 PWXL columns(Sursee, Switzerland) connected to an Agilent 1260 Infinity Multi-Detector GPC/SEC system(Santa Clara, United States), and a refractive index detector. Analyses were performed with buffer citrate/phosphate $0.15 \mathrm{M}+0.1 \mathrm{M} \mathrm{NaCl} \mathrm{pH} 5$ as eluent with a flow of $1 \mathrm{~mL} / \mathrm{min}$ and poly(ethylene oxide) standard $(40 \mathrm{kDa})$ to obtain the calibration curve. The column temperature was set at $30^{\circ} \mathrm{C}$.

\subsection{Potentiometric Titration of PHEA-g-bAPAE Graft Copolymer}

\subsubsection{Qualitative Titration of PHEA-g-bAPAE Copolymer}

To determine the relative buffering capacity of PHEA-g-bAPAE copolymer, potentiometric acid-base titrations were performed. Typically, $6 \mathrm{mg}$ of copolymer was dissolved in $30 \mathrm{~mL}$ in $0.1 \mathrm{~N}$ $\mathrm{NaCl}$, used as ionic strength stabilizer, and the $\mathrm{pH}$ was adjusted to nearly 10.0 using $0.1 \mathrm{~N}$ sodium hydroxide. Then the mixture was titrated by gradually adding $20 \mu \mathrm{L}$ of $0.1 \mathrm{~N} \mathrm{HCl}$ until reaching $\mathrm{pH} 3$. 
Titrations of comparable amounts of PHEA, and bAPAE, calculated considering the derivatization degree of the PHEA-g-bAPAE copolymer, at the same concentration present in PHEA-bAPAE, were also studied.

\subsubsection{Determination of the pKa Values of PHEA-g-bAPAE Copolymer by Potentiometric Titration}

$30 \mathrm{mg}$ of PHEA-g-bAPAE were dissolved in $0.1 \mathrm{~N}$ degassed $\mathrm{NaCl}(30 \mathrm{~mL})$, used as ionic strength stabilizer, and termostated at $25^{\circ} \mathrm{C}$ under argon atmosphere. The solution was then titrated using $0.05 \mathrm{~N} \mathrm{HCl}$ until $\mathrm{pH} 3$ under inhert conditions. Backward titrations were performed using $0.05 \mathrm{~N}$ $\mathrm{NaOH}$. For all titrations an AMEL 631 differential electrometer was used, which was calibrated against a set of multiple standard buffers $(2.50 \pm 0.01 \leq \mathrm{pH} \leq 10.00 \pm 0.01)$. The pKa values of the amine groups were extrapolated using the De Levie method of acid-base chemical equilibria for polyelectrolytes.

\subsection{Biological Studies}

\subsubsection{Cell Culture}

In this study, an immortalized normal bronchial epithelial cell line (16-HBE) was used (furnished by Istituto Zoo-profilattico of Lombardia and Emilia Romagna). 16-HBE cells were maintained in a humidified atmosphere of $5 \% \mathrm{CO}_{2}$ in air at $37^{\circ} \mathrm{C}$, cultured as adherent monolayers in Dulbecco's Modified Eagle's medium (DMEM) (EuroClone), supplemented with 10\% fetal bovine serum (FBS) (Gibco), $2 \mathrm{mM}$ L-glutamine (EuroClone), $100 \mathrm{U} / \mathrm{mL}$ penicillin, $100 \mathrm{~g} / \mathrm{mL}$ streptomycin, and $0.6 \mathrm{~g} / \mathrm{mL}$ amphotericin B (Sigma-Aldrich, Milan, Italy).

\subsubsection{Membrane Destabilization Study}

16-HBE cells were plated on a 48-well plate at a cell density of 10.000 cells/well in DMEM containing $10 \%$ FBS. After $24 \mathrm{~h}$ of incubation, the medium was removed and then the cells were incubated with $100 \mu \mathrm{L}$ of DPBS (pH 7.4) or $20 \mathrm{mM}$ MES (pH 5.5, $130 \mathrm{mM} \mathrm{NaCl}$ ) containing PHEA-g-bAPAE $(0.5 \mathrm{mg} / \mathrm{mL}$ ) for $20 \mathrm{~min}$ at $37^{\circ} \mathrm{C}$; in the same condition, blank analysis was also performed. After this time, $100 \mu \mathrm{L}$ of Tripan Blue $0.2 \%$ was added to each well. After $1 \mathrm{~min}$ of incubation, the supernatant was removed and cells were observed with miscroscope (Axio Cam MRm, Zeiss, Oberkochen, Germany). All analysis was performed in triplicate. Simultaneously, 16-HBE cells were plated on a 24-well plate at a cell density of 100,000 cells/well in DMEM containing 10\% FBS. After $24 \mathrm{~h}$ of incubation, the medium was removed and then the cells were incubated with $100 \mu \mathrm{L}$ of PBS ( $\mathrm{pH} 7.4$ ) or $20 \mathrm{mM}$ MES (pH 5.5, $130 \mathrm{mM} \mathrm{NaCl})$ containing PHEA-g-bAPAE $(0.5 \mathrm{mg} / \mathrm{mL})$ for $20 \mathrm{~min}$ at $37^{\circ} \mathrm{C}$; in the same condition, blank analysis was also performed. After this time $500 \mu \mathrm{L}$ of Trypsin was added in each well and after 5 min the content of 3 well, treated with the same condition, was reunited in a small centrifuge tube and mixed with $200 \mu \mathrm{L}$ of Trypan Blue $0.2 \%$. After 1 min the supernatant was removed by centrifugation at $2000 \mathrm{rpm}$ and the residual pellet was washed with $2 \mathrm{~mL}$ of DPBS. After washing, the supernatant was removed by centrifugation at $2000 \mathrm{rpm}$ and the pellet in each tube was treated with $250 \mu \mathrm{L}$ of TRITON X100 1\% and plated on a 96-well plate. After $1 \mathrm{~h}$ of incubation, the absorbance at $580 \mathrm{~nm}$ was read using a Microplate reader (Multiskan Ex, Thermo Labsystems, Vantaa, Finland). All analysis was performed in duplicate.

\subsubsection{Cell Viability Assay}

Cell viability was assessed by a MTS assay on 16-HBE cells, using a commercially available kit (Cell Titer 96 Aqueous One Solution Cell Proliferation assay, Promega) containing 3-(4,5-dimethylthiazol-2-yl)-5-(3-carboxymethoxyphenyl)-2-(4-sulphophenyl)-2H-tetrazolium (MTS) and phenazine ethosulfate. 16-HBE cells were plated on a 96-well plate at a cell density of 25,000 cells/well in DMEM containing $10 \%$ FBS. After $24 \mathrm{~h}$ of incubation, the medium was removed and then the cells were incubated with $200 \mu \mathrm{L}$ per well with an aqueous dispersion (DMEM containing $10 \% \mathrm{FBS}$ ) of each copolymer at concentrations between $2 \mathrm{mg} / \mathrm{mL}$ to $0.0625 \mathrm{mg} / \mathrm{mL}$. All polymers dispersions were sterilized by filtration using $220 \mathrm{~nm}$ filter. After 24 and $48 \mathrm{~h}$ incubation, the polymers dispersions were 
removed and each plate was washed with sterile DPBS; after this, cells in each well were incubated with with $100 \mu \mathrm{L}$ of fresh DMEM and $20 \mu \mathrm{L}$ of a MTS solution and plates were incubated for $2 \mathrm{~h}$ at $37^{\circ} \mathrm{C}$. The absorbance at $490 \mathrm{~nm}$ was read using a Microplate reader (Multiskan Ex, Thermo Labsystems, Finland). Relative cell viability (percentage) was expressed as (Abs490 treated cells/Abs490control cells) $\times 100$, on the basis of three experiments conducted in multiple of six. Cells incubated with the medium were used as negative control.

\subsection{Complexation Study}

Complexation study were evaluated by gel retardation assay and by measurements of size and potential. Polyplex were formed by adding a volume of the copolymer dispersion at different concentrations to the same volume of siRNA solution at a fixed concentration, in order to obtain different polymer/siRNA weight ratios (R); the mixture was mixed by gently pipetting, followed by $30 \mathrm{~min}$ incubation at room temperature, before analysis. For gel retardation assay, siRNA/copolymer polyplexes were formed in nuclease free Hepes buffer $10 \mathrm{mM}$, at pH7.4, containing glucose $5 \%(w / v)$. siRNA concentration was $0.1 \mathrm{mg} / \mathrm{mL}$ and polymer/siRNA weight ratios (R) were: $0,1,2,2.5,3,3.5$, 4 , and 5 . Ten microliters of each sample were then loaded on a $1.5 \%$ agarose gel, containing $70 \mathrm{~mL}$ ethidium bromide and run at $100 \mathrm{~V}$ in trisacetate/EDTA (TAE) buffer at pH 8 for 30 min. The gels were then visualized against an UV trans-illuminator and photographed using a digital camera. For dynamic light scattering studies (DLS), siRNA/copolymer polyplexes were formed in nuclease free Hepes buffer $10 \mathrm{mM}$, at pH 7.4. siRNA concentration was $0.05 \mathrm{mg} / \mathrm{mL}$ and $\mathrm{R}$ were $0,1,2,2.5,3,4,5,7$, and 10. DLS measurements were performed on $50 \mu \mathrm{L}$ of sample at $25^{\circ} \mathrm{C}$ with a Malvern Zetasizer NanoZS instrument fitted with a $532 \mathrm{~nm}$ laser at a fixed scattering angle of $173^{\circ}$, using the Dispersion Technology Software 7.02. For potential, siRNA/copolymer polyplexes were formed in nuclease free Hepes buffer $10 \mathrm{mM}$, at pH7.4. siRNA concentration was $0.2 \mathrm{mg} / \mathrm{mL}$ and $\mathrm{R}$ were $0,1,2,2.5,3,4$, 5,7 , and 10. Four hundred microliters of each sample was diluted with Hepes buffer until $900 \mu \mathrm{L}$ befeore measure. potential measurements were performed by aqueous electrophoresis measurements, recorded at $25{ }^{\circ} \mathrm{C}$ using the same apparatus for DLS measurement. The potential values $(\mathrm{mV})$ were calculated from the electrophoretic mobility using the Smoluchowski relationship.

\subsection{Polyplex Stability in Presence of Mucin}

\subsubsection{Polyanionic Exchange}

The stability of polyplexes to polyanionic exchange was determined after polyplexes incubation with mucin dispersion. Polyplexes were prepared as described before in gel retardation assay; the resulting polyplexes $(30 \mu \mathrm{L})$, were mixed with $5 \mu \mathrm{L}$ of mucin dispersion $(7 \mathrm{mg} / \mathrm{mL})$, in order to have a final mucin concentration of $1 \mathrm{mg} / \mathrm{mL}$, and samples were incubated at room temperature for 2 or $5 \mathrm{~h}$. Gel electrophoresis was then performed as described in complexation study.

\subsubsection{Turbidimetric Assay}

Measurements of interactions between polyplexes and mucin was determined by turbidimetry. $50 \mu \mathrm{L}$ of polyplexes, prepared as described in gel retardation assay, were mixed with $50 \mu \mathrm{L}$ of mucin dispersion at the concentration of $2 \mathrm{mg} / \mathrm{mL}$ in Hepes buffer $10 \mathrm{mM} \mathrm{pH} \mathrm{7.4.} \mathrm{After} \mathrm{incubation} \mathrm{at} 37^{\circ} \mathrm{C}$, the turbidity was measured each $50 \mathrm{~min}$ until $6 \mathrm{~h}$ approximately. The absorbance at the $\lambda$ of $500 \mathrm{~nm}$ was recorded by Microplate reader (Multiskan Ex, Thermo Labsystems, Finland).

\subsection{Gene Silencing Assay}

The evaluation of the gene silencing capacity was evaluated by ELISA test, using a IL-4 Human ELISA Kit kits from Life Technologies. 16-HBE cells were plated on a 96-well plate at a cell density of 25,000 cells/well in DMEM containing 10\% FBS. After $24 \mathrm{~h}$ of incubation, the medium was removed and then the cells were incubated with $200 \mu \mathrm{L}$ of a polyplexes dispersion (for each well $0.01 \mathrm{nmol}$ of siRNA was used) at different $R(3,5,10)$ for $48 \mathrm{~h}$; after this time supernatant was removed ed the cells 
were incubated with $200 \mu \mathrm{L}$ of LPS $500 \mathrm{ng} / \mathrm{mL}$ for $6 \mathrm{~h}$. After this time cells was washed with DPBS and treated following the protocol provided. For this study polyplexes were formed in OPTIMEM medium using a siRNA $0,1 \mu \mathrm{M}$. LPS, copolymers, and siRNA solution were sterilized by filtration using $220 \mathrm{~nm}$ filter before analysis.

\section{Results and Discussion}

\subsection{Polymer Synthesis and Characterization}

An ideal carrier for achieving the delivery of genetic material into a target tissue must be able, after in vivo administration, to interact with specific cells and to release the genetic material in the cytosol of target cells, overcoming both cellular membrane or the endosomal-lysosomal membrane $[7,25]$. Synthetic polycations represents in principle valid candidates in this field, thanks to the fact that can be realized with proper structural and functional properties able to confer specific characteristics that a vector of genetic material should have [7]. For this reason, the researchers explored the possibility of producing protonable copolymers with various functionalities in order to confer different properties to a single macromolecule.

Here, a novel polycation derivative of $\alpha, \beta$-poly(N-2-hydroxyethyl)-D,L-aspartamide (PHEA) was produced by grafting on the PHEA backbone the 1,2-Bis(3-aminopropylamino)ethane (bAPAE), obtaining the PHEA-g-bAPAE graft copolymer. The grafting of bAPAE molecules on PHEA backbone allow to realise a copolymer carrying on the side chains with protonable amines conferring the capability to complex the genetic material by electrostatic interactions.

The reaction involved the activation of free PHEA hydroxyl groups with bis-nitrophenyl carbonate (BNPC), chosing the stoichiometry of reagents in order to obtain deficiency of BNPC over hydroxyl groups of repeating units (6:10). Using this strategy we obtained a suitable amount of activated groups able to further react with amine functions of bAPAE. However, being a polyamine, a huge excess bAPAE was employed is the second step of the reaction, thus avoiding crosslinking owing to multiple nucleofilic attack of side chains. In these experimental conditions, a derivatization degree in bAPAE (DD bAPAE$_{\text {) }}$ of PHEA-g-bAPAE graft copolymer of about $35 \mathrm{~mol} \%$ was obtained. The latter was calculated by ${ }^{1} \mathrm{H}-\mathrm{NMR}$ analysis by using the ratio between the integral of the signals corresponding to $4 \mathrm{H}$ of bAPAE (at $\delta 1.70$ and $2.20 \mathrm{ppm}$ ), to the integral of the signal corresponding to $2 \mathrm{H}$ of PHEA repeating unit (at $\delta 2.73 \mathrm{ppm}$ ); it was confirmend by the colorimetric TNBS assay, that gives a DD\% value superimposable to that obtained by ${ }^{1} \mathrm{H}-\mathrm{NMR}$ analysis [12]. The occurring of the conjugation of 1,2-Bis(3-aminopropylamino)ethane (bAPAE) was demonstrated also by the appearance of signal at about $\delta 4.1$, related to the $\mathrm{CH}_{2}$ of the side chain of functionalized PHEA repeat unit $\left(\mathrm{NHCH}_{2} \mathrm{CH}_{2} \mathrm{OCO}-\right)$ near to the OCONH bond. The scheme or reaction is reported in Figure 2a.

The obtained copolymer was further characterised by SEC analysis in terms of weight average molecular weight $\left(\overline{\mathrm{M}}_{\mathrm{w}}\right)$ and polydispersity index $\left(\overline{\mathrm{M}}_{\mathrm{w}} / \overline{\mathrm{M}}_{\mathrm{n}}\right)$ (for SEC chromatogram, see Figure S1 in Supplementary Materials), and obtained values are reported in Table 2, together with $\mathrm{DD}_{\text {Bapae }}$ value.

Table 2. Weight-average molecular weight $\left(\overline{\mathrm{M}}_{w}\right)$, polydispersity index $\left(\overline{\mathrm{M}}_{\mathrm{w}} / \overline{\mathrm{M}}_{\mathrm{n}}\right)$, and chemical composition of obtained copolymers.

\begin{tabular}{ccccc}
\hline \multirow{2}{*}{ Copolymers } & \multicolumn{2}{c}{ Molecular Weight } & \multicolumn{2}{c}{ Degree of Derivatization (DD) } \\
\cline { 2 - 5 } & $-\mathbf{M}_{\mathbf{w}}(\mathbf{g} / \mathbf{m o l})$ & $\mathbf{M}_{\mathbf{w}} / \mathbf{M}_{\mathbf{n}}$ & DD $_{\mathbf{P E G}}$ & DD $_{\mathbf{b A P A E}}$ \\
\hline PHEA & 67500 & 1.24 & - & - \\
PHEA-g-PEG(A) & 82,410 & 1.2 & 1.9 & - \\
PHEA-g-PEG(B) & 95,360 & 1.3 & 2.7 & - \\
PHEA- $g$-PEG(C) & 110,800 & 1.3 & 4.4 & - \\
PHEA-g-bAPAE & 20,921 & 1.41 & - & 34 \\
PHEA-g-PEG(A)-g-bAPAE & 25,400 & 1.32 & 1.9 & 35 \\
PHEA-g-PEG(B)-g-bAPAE & 32,100 & 1.35 & 2.7 & 36 \\
PHEA-g-PEG(C)-g-bAPAE & 34,700 & 1.41 & 4.4 & 33 \\
\hline
\end{tabular}




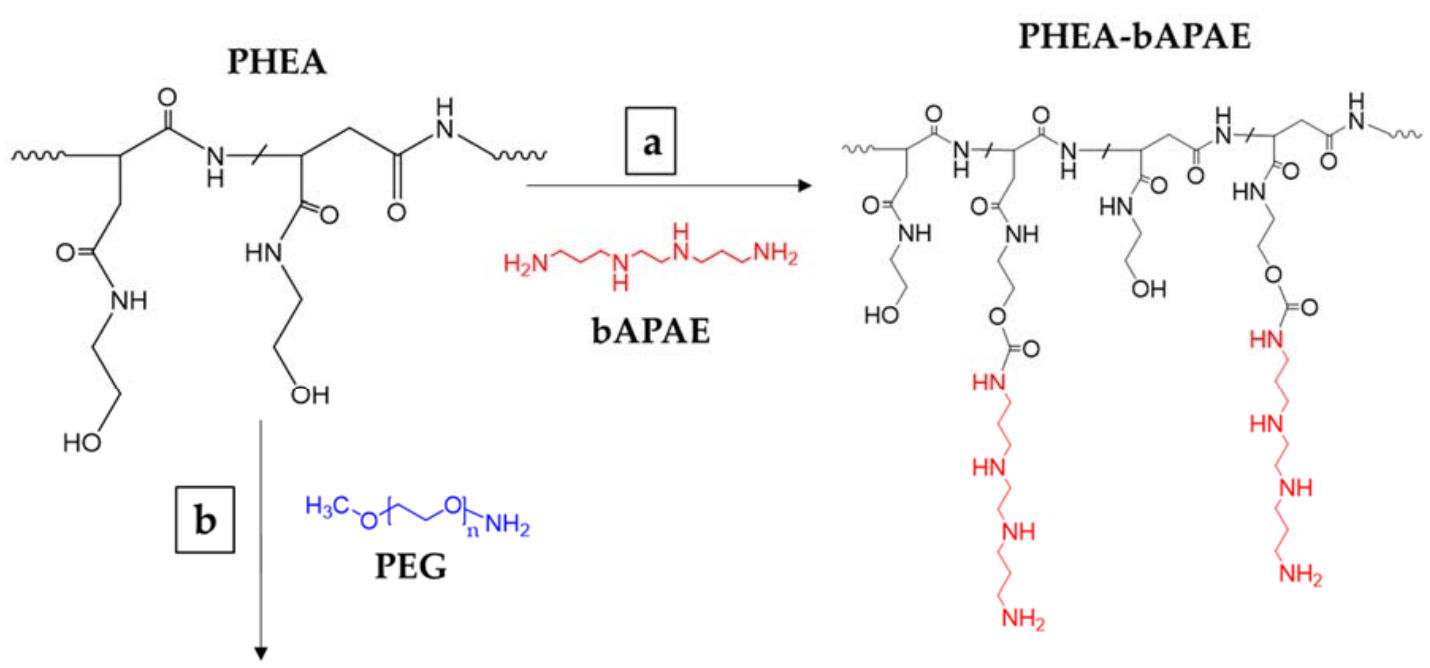

PHEA-PEG
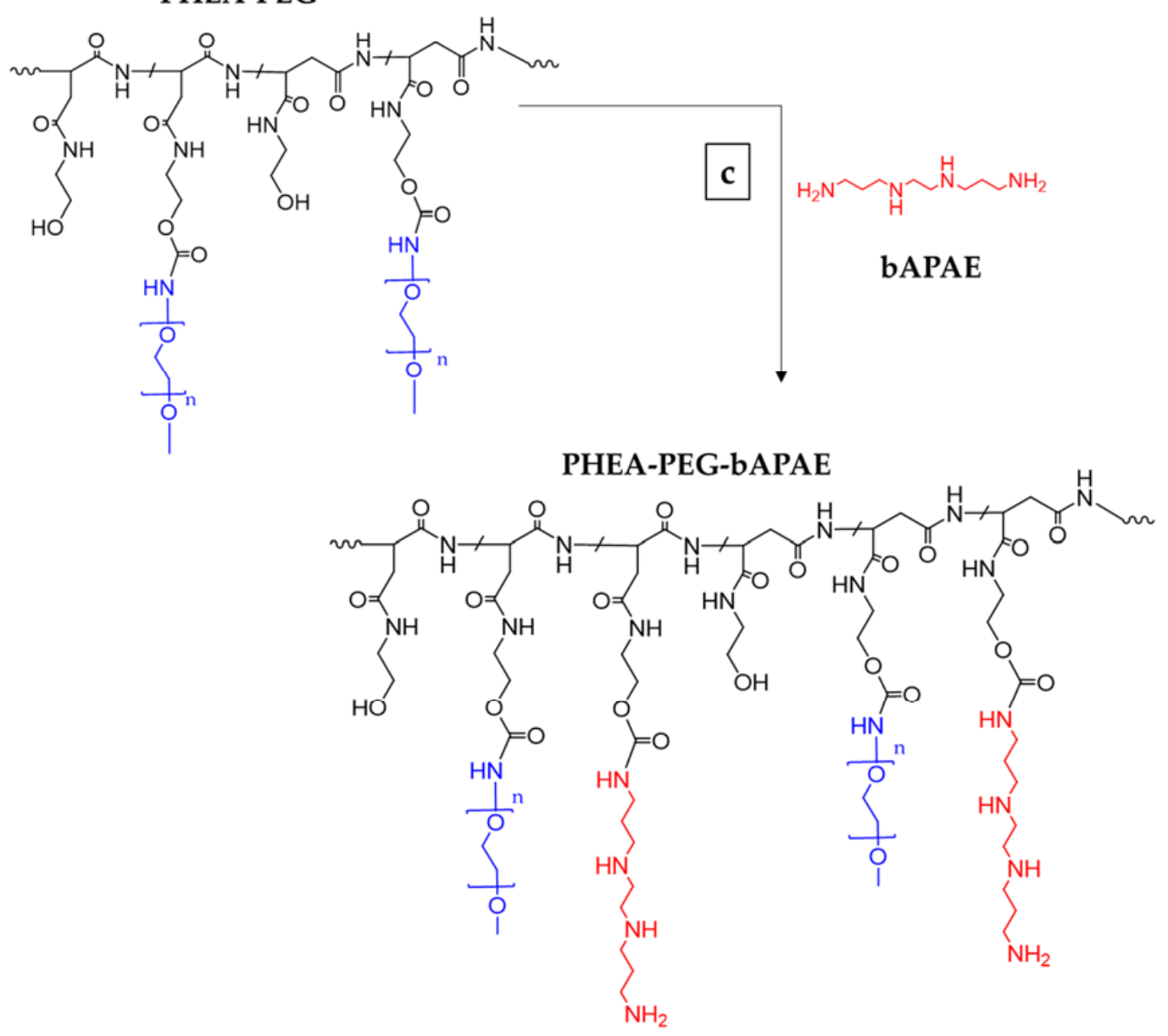

Figure 2. The synthetic route of (a) PHEA-g-bAPAE and (b) PHEA- $g$-PEG and (c) PHEA- $g$-PEG- $g$-bAPAE graft copolymers $(n=44)$. Reagents and conditions: a) a-DMF, BNPC, $4 \mathrm{~h}$ at $40{ }^{\circ} \mathrm{C}, 20 \mathrm{~h}$ at $25^{\circ} \mathrm{C} ; \mathrm{b}$ ) a-DMF, DSC, $4 \mathrm{~h}$ at $40{ }^{\circ} \mathrm{C}, 18 \mathrm{~h}$ at $25^{\circ} \mathrm{C}$; b) a-DMF, BNPC, $4 \mathrm{~h}$ at $40{ }^{\circ} \mathrm{C}, 20 \mathrm{~h}$ at $25^{\circ} \mathrm{C}$.

As previously evidenced for other reactions of amine with PHEA, the $\overline{\mathrm{M}}_{\mathrm{w}}$ undergoes a rather drastic reduction, due to the experimental condition to achieve high degree of functionalizations [26]. This fact could be explained with the use of a high amount of amine (four times compared to the RU of PHEA) for carrying out the functionalization reaction of PHEA with bAPAE, that could break some 
amide bound in the main chain. However authors can not exclude that also the modification of the copolymer conformation respect to that parent polymer can be the reason of the detection of lower molecular weight of copolymers by SEC. However, the use of materials with low $\overline{\mathrm{M}}_{\mathrm{w}}$ is often preferred as polymeric carriers for complexing genetic material [7].

The functionalization of PHEA with bAPAE was done in order to: (a) Make the polymer susceptible to $\mathrm{pH}$ changes, that is, modulable in terms of charges to be used for complexing genetic material; and (b) confer it a buffering behavior, that is also a main characteristic request to a genetic vector in order to increase the possibility of giving rise to endosome/lysosome escape, once internalized by cells, due to the so-called proton spoge effect [7].

The buffering behavior of PHEA-g-bAPAE graft copolymer was investigated by an acid-base titration. The titration profile was also obtained for PHEA or bAPAE, in aqueous dispersions, at concentrations present in PHEA-g-bAPAE dispersion. Data are reported in Figure 3.

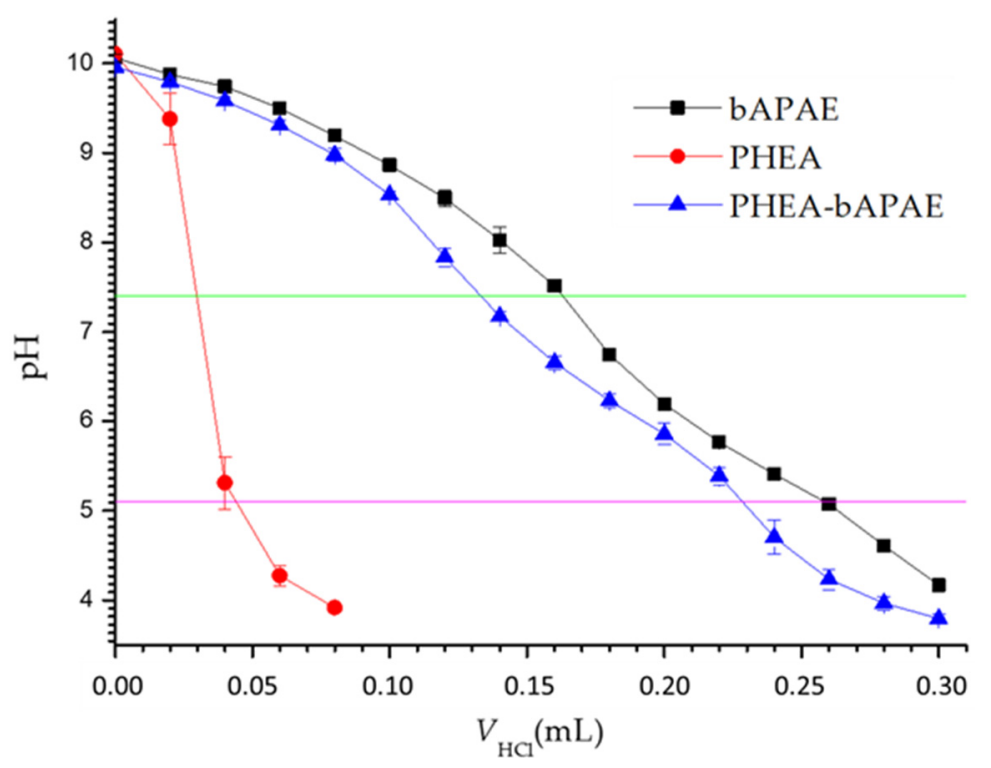

Figure 3. Acid-base titration profiles ( $\mathrm{pH}$ versus acid volume) of PHEA-g-bAPAE $(0.2 \mathrm{mg} / \mathrm{mL}) \mathrm{graft}$ copolymer, PHEA $(0.2 \mathrm{mg} / \mathrm{mL})$ and bAPAE moieties $(0.047 \mathrm{mg} / \mathrm{mL})$.

As is evidenced in the graphic, PHEA-g-bAPAE copolymer shows a buffering capability in the $\mathrm{pH}$ interval from 7.4 (extracellular and cytoplasmatic $\mathrm{pH}$ ) to 5.1 (endosomal/lysosomal $\mathrm{pH}$ ), important for endosomal escaping with proton sponge effect $[7,27,28]$. Moreover, the PHEA-g-bAPAE titration profile show a buffering behavior quite superimposable to that obtained by the bAPAE alone. On the contrary, the titration curve of PHEA dispersion showed rapid reduction in $\mathrm{pH}$ value, suggesting (as expected) no buffering capacity. This result indicates that the conjugation of the amine confers to the polymeric backbone the buffering capability of the amine itself.

A further potentiometric titration was performed in order to determine the $\mathrm{K}_{\mathrm{a}}$ constants; titration plot of backward was elaborated using Origin software according to the De Levie method of acid-base equilibria for polyprotic acid and bases, taking into account the activity corrections through the Davies expression (1) [29-32].

$$
\log y=-0,5\left(\frac{\sqrt{I}}{1+\sqrt{I}}-0,3 I\right)
$$

where $y$ is the activity coefficient and I is the ionic strength.

For this titration, the fitting function obtained is the following (2):

$$
V_{B}=-\frac{V_{0}\left[C_{0}\left(3 \alpha_{3}+2 \alpha_{2}+\alpha_{1}\right)+\Delta\right]+V_{A}\left(\Delta-C_{A}\right)}{\Delta+C_{B}}
$$




$$
\Delta=C_{H^{+}}-\frac{K_{W}}{C_{H^{+}} \cdot y^{2}}+C_{B}
$$

where $V_{B}$ and $C_{B}$ are respectively the volume and molarity of $\mathrm{NaOH}$ for the backword titration, $V_{0}$ is the volume of $\mathrm{NaCl}$ using for dissolving PHEA-g-bAPAE, $\mathrm{C}_{0}$ is the analyte molarity, $\mathrm{V}_{\mathrm{A}}$ and $\mathrm{C}_{\mathrm{A}}$ are respectively the volume and molarity of $\mathrm{HCl}$ used for the forward titration, while $\alpha_{3}, \alpha_{2}, \alpha_{1}$ are the protonation degree, $\mathrm{K}_{\mathrm{W}}$ is the dissociation constant of water and $\mathrm{C}_{\mathrm{H}^{+}}$is the $\mathrm{H}^{+}$concentration.

The titration profile and the fitting are reported in Figure 4.

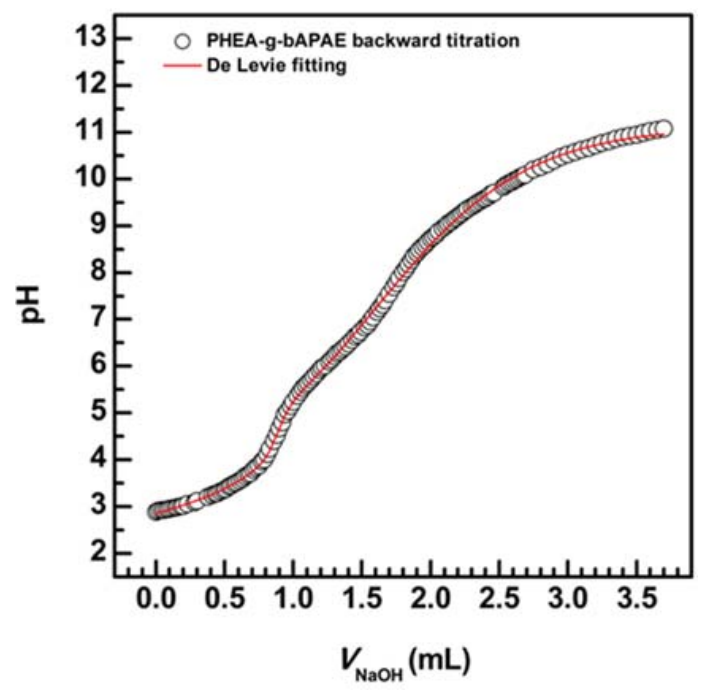

Figure 4. Backward acid-base titration ( $\mathrm{NaOH}$ volume versus $\mathrm{pH}$ ) of PHEA-g-bAPAE and De Levie fitting curve.

Obtained $\mathrm{pK}_{\mathrm{a} 1}, \mathrm{pK}_{\mathrm{a} 2}$, and $\mathrm{pK}_{\mathrm{a} 3}$ values from the curve fitting analysis were found, respectively, equal to $4.8,7.9$, and 10.9 .

As shown in Figure 5, at pH 7.4 the diprotonated species $\left(\mathrm{L}^{+2}\right)$ is the mostly present, while, as the $\mathrm{pH}$ value of the medium decreases, the amount of the triprotonated species $\left(\mathrm{L}^{+3}\right)$ begins to increase, until becoming the mostly present species at a $\mathrm{pH}$ value approximately of 4.5 . This behavior could determine a different effect of the copolymer on the biological membranes dependin on the $\mathrm{pH}$ of the medium, i.e., on cytosolic membranes at $\mathrm{pH} 7.4$ and on endosomal membranes at $\mathrm{pH} 5$ (more or less), demonstrated in our next study.
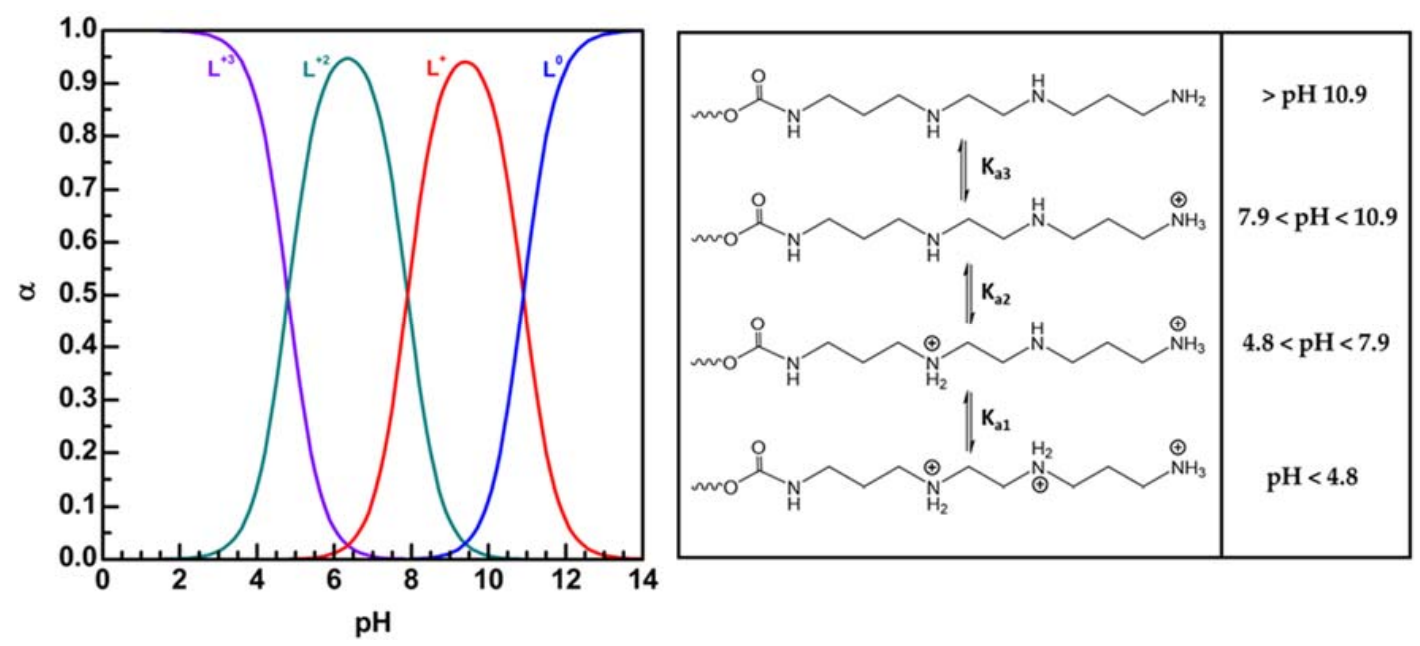

Figure 5. Speciation curves obtained for Plot $\alpha$ versus $\mathrm{pH}$ for each $\alpha$ of PHEA-bAPAE PHEA-g-bAPAE and protonation state of PHEA-bAPAE PHEA- $g$-bAPAE at different $\mathrm{pH}$ values. 


\subsubsection{Membrane Destabilization Study}

Once proved its buffering behaviour, the copolymer effect on cell membranes was evaluated in detail as a function of the $\mathrm{pH}$ of the medium, i.e., depending on the amount of protonate amines on its structure, by mimicking the cytosol ( $\mathrm{pH} 7.4$ ) and the lysosomal compartment (pH 5).

Therefore, an in vitro study was carried out by using human bronchial cells (16-HBE) as biological membrane model and by incubating these cells in the presence of PHEA- $g$-bAPAE graft copolymer in an aqueous dispersion at two different $\mathrm{pH}$ values of the medium: 7.4 and 5. Trypan blue was used as colorant to distinguish healthy cells from those that are dead or in apoptotic state under the microscope, as it is capable of entering cells only when the membranes are destabilized. After incubation for $20 \mathrm{~min}$, cell were treated with Trypan blue and images were recorded and reported in Figure 6.

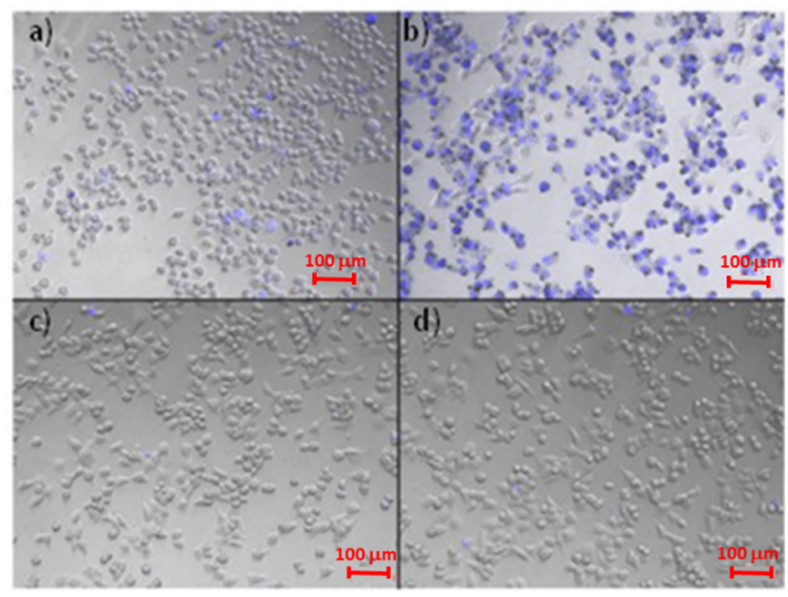

Figure 6. Microscope pictures of 16-HBE treated in different ways: (a) cells treated with PHEA-g-bAPAE in DPBS pH 7.4. (b) cells treated with PHEA-g-bAPAE in isotonic MES $20 \mathrm{mM} \mathrm{pH} \mathrm{5,} \mathrm{(c)} \mathrm{cells} \mathrm{treated}$ with DPBS pH 7.4, (d) cells treated with isotonic MES $20 \mathrm{mM}$ pH5.

As shown in figure, considerable cell membrane destabilization occurs only when cell are treated with PHEA-g-bAPAE at $\mathrm{pH} 5$, that is in the protonated state, as demonstrated by the fact that trypan blue has free access to all cells. This phenomenon is due to the fact that at $\mathrm{pH} 5$, most of the polymeric species in solution are in the diprotonated state $(60 \%)$ and in the triprotonated state $(40 \%)$, while at $\mathrm{pH} 7.4$ most of the polymeric species in solution are in the diprotonated state $(75 \%)$ and in the monoprotonated state (25\%), as showed in Figure 5.

To confirm this result, a quantification of the trypan blue amount was performed by ultraviolet spectrophotometry and obtained values are reported in Figure 7; data shown the maximum absorbance when cells are treated with PHEA-g-bAPAE, at $\mathrm{pH} 5$. Even if the quantification does not reflect the same behaviour seen in the microscope images, the results are in any case in agreement with what has been hypothesized, that is the destabilizing effect of the protonated PHEA-g-bAPAE graft copolymer on the cellular membrane as a function of $\mathrm{pH}$. 


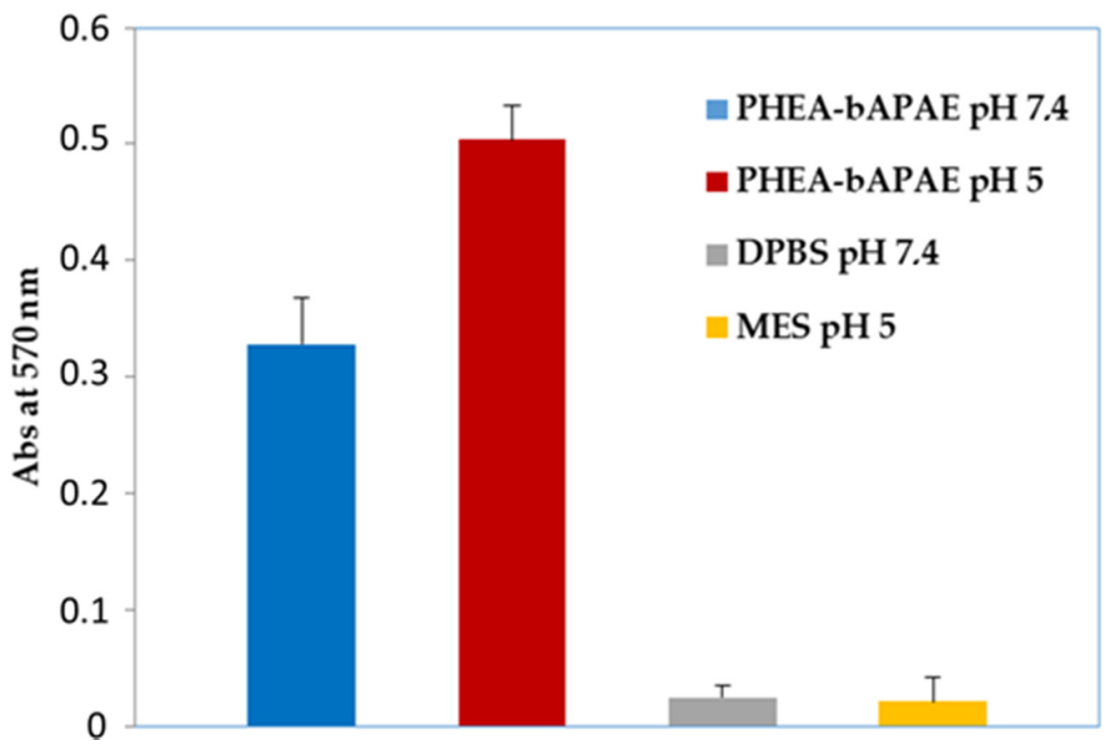

Figure 7. Destabilization assay: absorbance values at $570 \mathrm{~nm}$ (trypan blue) in 16-HBE cell dispersion after incubation with PHEA-g-bAPAE copolymer at different $\mathrm{pH}$ values.

\subsubsection{Pegylation}

The possibility of using as starting polymer a material that can be easily modified by conjugation with proper molecules is certainly an advantage in cases where it is necessary to take into account the peculiarity of the material to be transported and the barriers to be overcomed after in vivo administration. Here, the PHEA-g-bAPAE copolymer was thought to complex siRNA to form polyplexes to be administered by inhalation, then locally to the lung.

Polyethylenglycols (PEG) represent the proper material to influence the properties of the resulting conjugate, thanks to their unique properties such as hydrophilicity and biocompatibility [23]. In most of cases, pegylation of polyplexes provides reduction of toxicity, shielding and stealth properties. However, these improvements are often associated to as a reduction of siRNA condensation, which usually need in using higher amount of polymer [7].

To potentially minimize the tendency to aggregation of polyplexes and interactions with mucus components of lungs, i.e., mucin, PHEA was functionalised with polyethylene glycol (PEG) to obtain PHEA-g-PEG graft copolymer. It is well known from previously studies that the mucus-penetrating capability of colloidal carriers through the mucus layer is related to the pegylation degree $\left(\mathrm{DD}_{\mathrm{PEG}}\right)$ [23]. PHEA-g-PEG-g-bAPAE graft copolymer was synthesized by two reaction steps. In the first step, PHEA was left to react with methoxy(polyethylene glycol) amine $\left(\mathrm{CH}_{3} \mathrm{O}-\mathrm{PEG}-\mathrm{NH}_{2}\right)$ molecules by using disuccinimidyl carbonate (DSC) as coupling agent; while, in the second step, recovered PHEA-g-PEG was left to react with bAPAE by using BNPC as coupling agent. The schematic representation of both steps are reported in Figure 1b,c.

In order to obtain copolymers with a different pegylation degree and to evaluate the effect of the PEG amounts on the interactions with mucin of the resulting polyplexes with siRNA, three different theoretical molar ratio values between $\mathrm{CH}_{3} \mathrm{O}-\mathrm{PEG}-\mathrm{NH}_{2}$ molecules and PHEA RU $\left(\mathrm{R}_{1}=0.03,0.075\right.$, and 0.12 ) were used to carry out the reaction, thus obtaining three different PHEA- $g$-PEG graft copolymers with increasing derivatization degrees (DD $D_{\text {PEG }} \mathrm{mol} \%$ ): 1.9, 2.7, and $4.4 \mathrm{~mol} \%$, named respectively PHEA- $g$-PEG(A), PHEA- $g$-PEG(B) and PHEA- $g$-PEG(C).

The DD values were calculated by ${ }^{1} \mathrm{H}-\mathrm{NMR}$ analysis as the ratio between the integral of the signals corresponding to protons on PEG (at $\delta 3.60 \mathrm{ppm}$ ), to the integral of those corresponding to $2 \mathrm{H}$ of PHEA repeating unit (at $\delta 3.24 \mathrm{ppm}$ ).

All the obtained PHEA-g-PEG copolymers were characterised in terms of $\overline{\mathrm{M}}_{w}$ and $\overline{\mathrm{M}}_{w} / \overline{\mathrm{M}}_{n}$ (for SEC chromatograms, see Figure S1 in Supplementary Materials), and obtained values are reported in 
Table 2, together with chemical composition expressed as DDPEG. The increase in the copolymer $\overline{\mathrm{M}}_{\mathrm{w}}$ is in accordance with the theoretical value calculated considering thr starting PHEA $\overline{\mathrm{M}}_{\mathrm{w}}$ value and the DD in PEG of each copolymer.

In the second step, PHEA or PHEA-g-PEG(A)-(C) graft copolymers were further functionalized with bAPAE by using BNPC, obtaining a DD $\mathrm{bAPAE}$ of each PHEA-g-PEG-g-bAPAE graft copolymers of about $35 \mathrm{~mol} \%$. The latter was calculated by ${ }^{1} \mathrm{H}-\mathrm{NMR}$ analysis as reported before for PHEA-g-bAPAE graft copolymer. The typical ${ }^{1} \mathrm{H}-\mathrm{NMR}$ spectrum of a PHEA-g-PEG- $g$-bAPAE graft copolymer is reported in Figure 8.

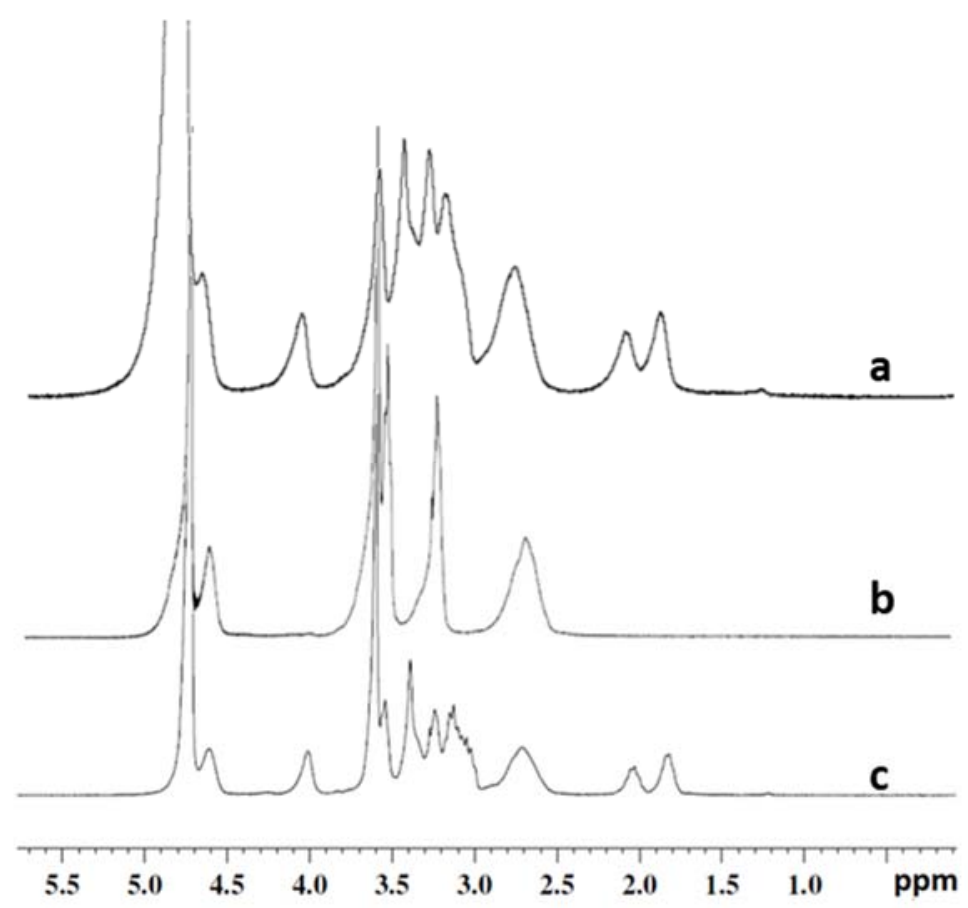

Figure 8. The typical ${ }^{1} \mathrm{H}-\mathrm{NMR}$ spectrum of a) PHEA- $g$-bAPAE $\left(\mathrm{D}_{2} \mathrm{O}\right.$ at $\left.\left.\mathrm{pD}<5\right), \mathbf{b}\right)$ PHEA- $g$-PEG(C) $\left(\mathrm{D}_{2} \mathrm{O}\right)$, and c) PHEA-g-PEG(C)- $g$-bAPAE $\left(\mathrm{D}_{2} \mathrm{O}\right.$ at $\left.\mathrm{pD}<5\right)$.

The obtained DD mol\% was also confirmend by the colorimetric TNBS assay, that gives a DD $\%$ value superimposable to that obtained by ${ }^{1} \mathrm{H}-\mathrm{NMR}$ analysis. All the obtained copolymers were characterised in terms of $\overline{\mathrm{M}}_{\mathrm{w}}$ and $\overline{\mathrm{M}}_{\mathrm{w}} / \overline{\mathrm{M}}_{\mathrm{n}}$ (for SEC chromatogram, see Figure S1 in Supplementary Materials), and obtained values are reported in Table 2, together with chemical composition espressed as DDPEG and $\mathrm{DD}_{\mathrm{bAPAE}} \mathrm{mol} \%$. In this case, the reduction in the $\overline{\mathrm{M}}_{\mathrm{W}}$ of each PHEA-g-PEG starting copolymer is in agreement with what described before for PHEA following the reaction with the amine bAPAE. Moreover, the differences between experimental and theoretical $\overline{\mathrm{M}}_{\mathrm{w}}$ values of PHEA- $g$-PEG- $g$-bAPAE graft copolymers could be attributed to conformational modifications of obtained copolymers in the aqueous medium depending on the amount of linked PEG.

\subsubsection{Cell Viability Assay}

Considering the potential application of the PHEA-g-bAPAE and/or PHEA-g-PEG-g-bAPAE graft copolymers as a starting material to realise a formulation for pulmonary administration of siRNA, cytocompatibility of all copolymers was evaluated by the MTS assay on 16-HBE cells at different concentrations, after 24 and 48 incubation. Results are shown in Figure 9a,b.

As can be seen, also after $48 \mathrm{~h}$ incubation, all copolymers showed a good cytocompatibility at all tested concentrations, showing a cell viability higher than $80 \%$ compared to the control experiment, where cells are incubated only with DMEM medium. 

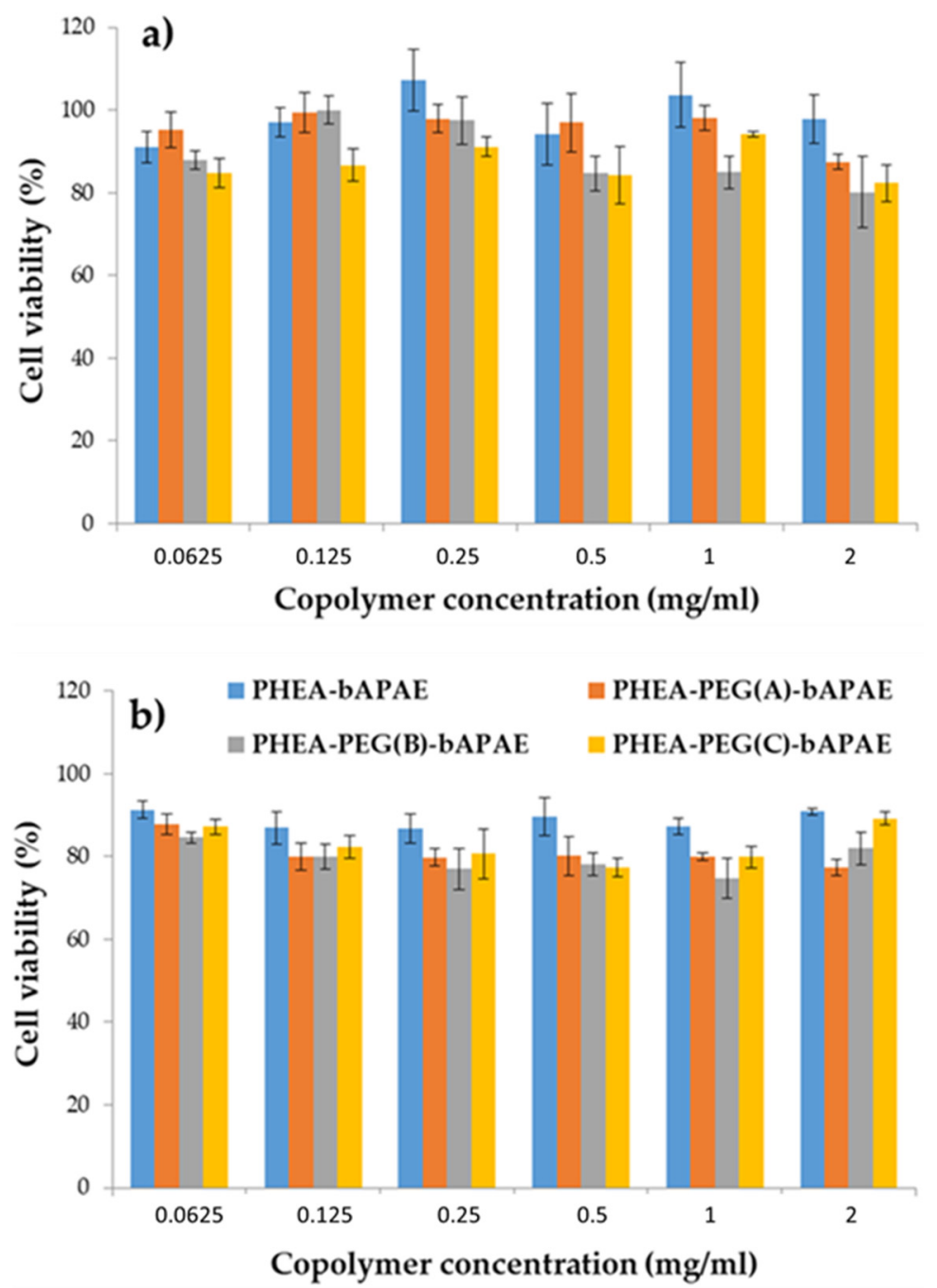

Figure 9. 16-HBE viability assay after (a) 24 and (b) $48 \mathrm{~h}$ of incubation with all copolymers.

\subsection{Complexation Studies and Characterization of Obtained Polyplexes}

The obtained copolymers, PHEA- $g$-bAPAE, PHEA- $g$-PEG(A)- $g$-bAPAE, PHEA- $g$-PEG(B)- $g$-bAPAE, and PHEA- $g$-PEG(C)- $g$-bAPAE, possess in their chemical structure an equal amount of amine (about $35 \mathrm{~mol} \%$ ) and increasing PEG chains (about 0, 1.9, 2.7, and $4.4 \mathrm{~mol} \%$ ) linked on the PHEA backbone, that could reduce the capability to the polyplexes to interact with mucus components but at the same time, the capability to electrostatically interact with siRNA and to be internalized by cells. For this reason, all four were used for the subsequent evaluation of the siRNA complexing capacity. As therapeutic siRNA, a siRNA able to reduce the expression of STAT6 was chosen, that regulate the production of Th2 cytokines and effector functions mediated by Th2 cytokines [4], and that which seems to have a major role in the mechanism that initiates an asthmatic attack.

To understand if each synthetized copolymer can electrostatically bind negatively charged siRNA molecules, complexation studies were performed. To do this, a mixing of two equal volumes of two dispersions, on containing a fixed concentration of siRNA and the other one containing increasing concentration of each copolymer was done, in order to obtain different polymer/siRNA weight ratios (R) ranging between 1 and 5 . To evaluate the formation of stable complexes, an electrophoresis analysis on agarose gel was performed; results are reported in Figure 10. 


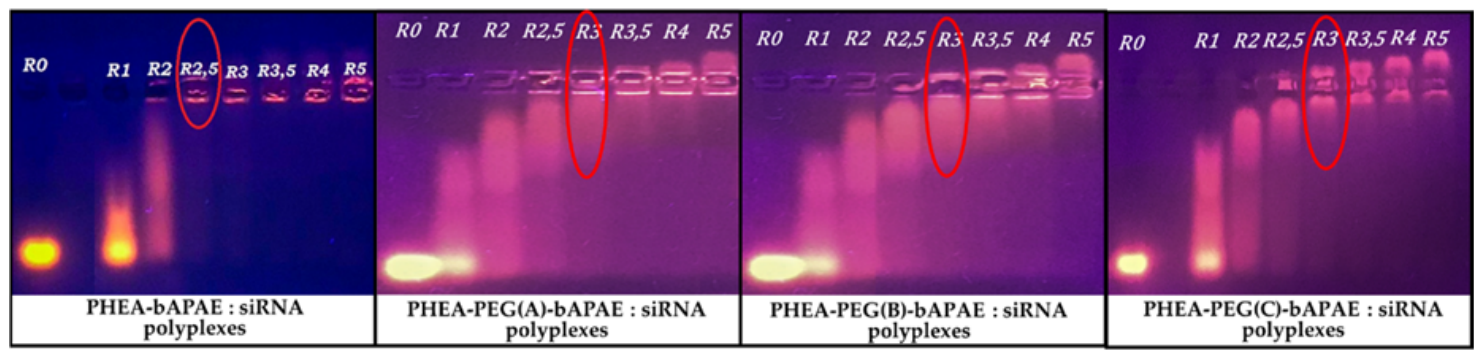

Figure 10. Agarose gel electrophoresis of polyplexes obtained in HEPES $10 \mathrm{mM}$ at various graft copolymer to siRNA weight ratios (R) ranging between 1 and 5 .

As can be seen in Figure 10, each PHEA-g-PEG-g-bAPAE copolymer was able to retard the electrophoresis run of siRNA molecules starting from a polymer/siRNA weight ratio of 3; on the other hand, PHEA- $g$-bAPAE was able to retard the electrophoresis run of siRNA molecules starting from a polymer/siRNA weight ratio of 2,5. This difference probably is due to the fact that the same amounts of PHEA- $g$-bAPAE and PHEA- $g$-PEG- $g$-bAPAE copolymers contain a different amounts of amine groups, that are higher in PHEA- $g$-bAPAE due to the absence of PEG chains in the polymeric backbone. In effect, if the N/P ratio is considered, it means that the unpegylated copolymer stop the siRNA run at N/P equal to 3.5, while for PHEA- $g$-PEG(A)-g-bAPAE, PHEA-g-PEG(B)-g-bAPAE PHEA-g-PEG(C)-g-bAPAE graft copolymers correspond to a N/P ratio of 3.5, 3.4, and 3, respectively. This result means that the pegylated copolymers were able to retard the electrophoresis run of siRNA molecules at lower N/P ratios than PHEA-g-bAPAE graft copolymer, and that increasing the PEG amount improves this behaviour. In all cases, the R need to stop the mobility of siRNA is quite low if compared to other synthetic copolymers proposed as non viral vectors for siRNA terapy, as reported elsewhere [7].

In order to confirm these results, the mean size, PDI and potential values of obtained polyplexes at different $R$ values (ranging between 1 and 10) were measured and obtained data reported in Figure 11 for each synthesized copolymer.

As expected, for PHEA-g-bAPAE based polyplexes, a negative potential is recorded for the lowest weight ratio; the potential increases then, up to the point of reversing itself, as a higher quantity of copolymer is mixed with siRNA. Regarding to size profile, higher dimensions of the polyplexes are measured as they present a potential near neutrality, which decrease when the potential of the polyplex increases; this phenomenon is due to the fact that near a zero potential, phenomena of aggregation between polyplexes occur, while when the potential deviates from neutrality, the phenomena of repulsion cause a reduction of this aggregation. For polyplexes obtained with pegylated copolymers, a slightly different behaviour is recorded. First, regarding the potential, there are no high potential values even for the greatest weight ratios, but a stasis is observed in the region of neutrality; this phenomenon gradually increases with the increase in the amount of PEG present in the polymeric backbone. This behaviour is probably due to the ability of the PEG chains to form a shell that shields the surface charges. But at the same time, this shell causes a reduction of the phenomena of aggregation; in fact, there are no large and quite static dimensions, especially for the complexes obtained by PHEA- $g$-PEG(C)-g-bAPAE, where the PEG amount is higher. Thus, the presence of PEG in the copolymer allows to obtain polyplexes with siRNA that does not aggregate while maintaining a charge close to neutrality. 

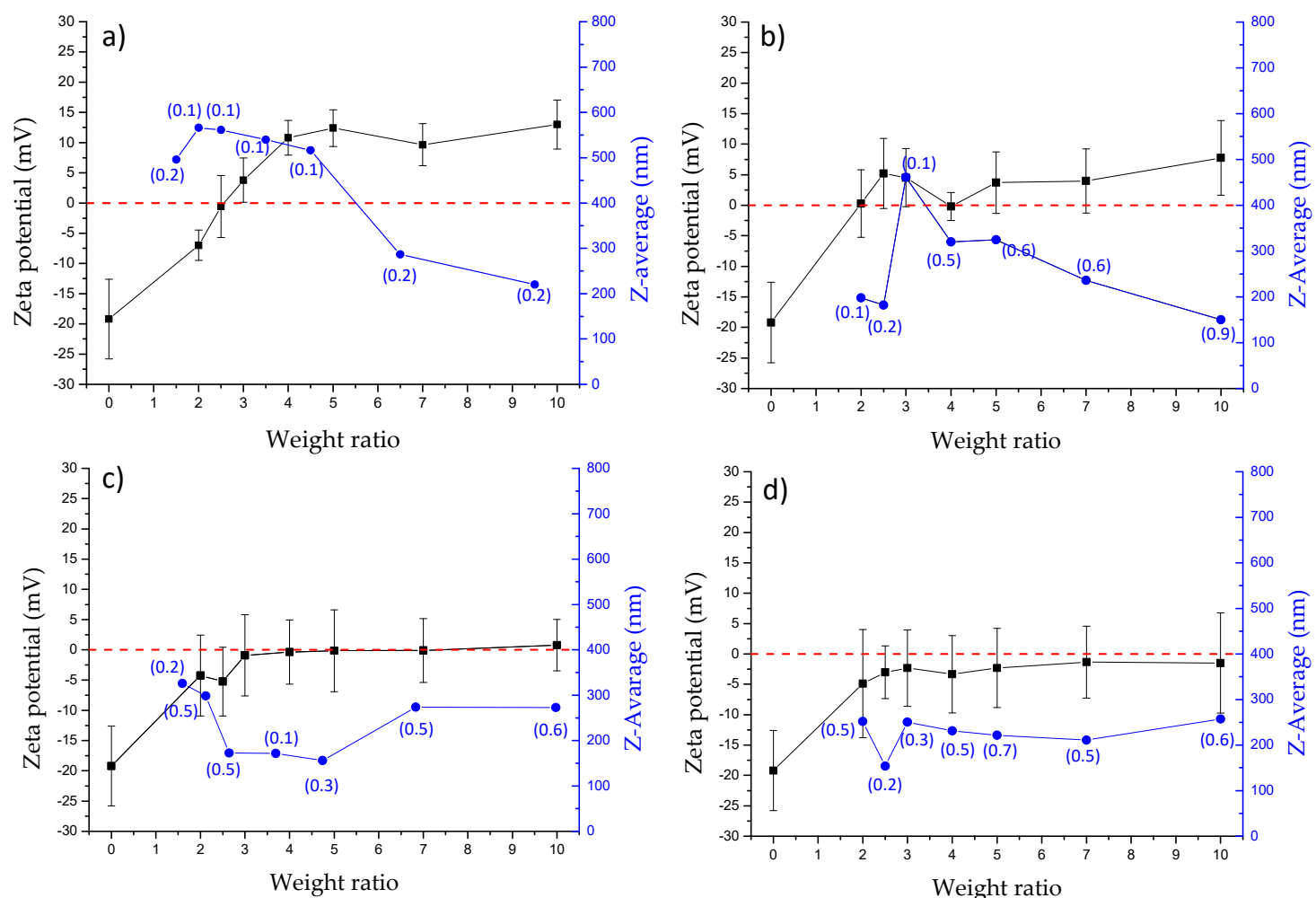

Figure 11. Mean size (blue line), PDI (value enclosed in brakets) and potential (black line) of polyplexes formed by siRNA and: (a) PHEA-g-bAPAE; (b) PHEA- $g$-PEG(A)- $g$-bAPAE; (c) PHEA- $g$-PEG(B)- $g$-bAPAE; (d) PHEA- $g$-PEG(C)- $g$-bAPAE graft copolymers, at weight ratios (R) ranging between 0 and 10 (data are reported as means $\mathrm{SD}, n=3$ ).

\subsection{Interaction Studies of Polyplexes with Mucin}

Being the copolymer/siRNA complexes in view to be administered by the inhalation route, it was necessary to assess whether these polyplexes interact with the mucin and if the presence of PEG in the copolymer structure can effectively influence these interactions, given that the mucus layer represents the main barrier that the inhaled particles must overcome.

The first study was carried out considering that, given the polyanionic nature of the mucin (due to the presence of sialic acid residues), a polyanionic exchange between siRNA and mucin may occur. Thus, a study was carried out by evaluating the electrophoretic mobility of siRNA in the polyplexes in the presence of mucin in the dispersion medium. In particular, the study was carried out in the presence of mucin at a concentration of $1 \mathrm{mg} / \mathrm{mL}$, for 2 and $5 \mathrm{~h}$. Obtained images for $\mathrm{R}=5$ and 10 are reported in Figure 12. 

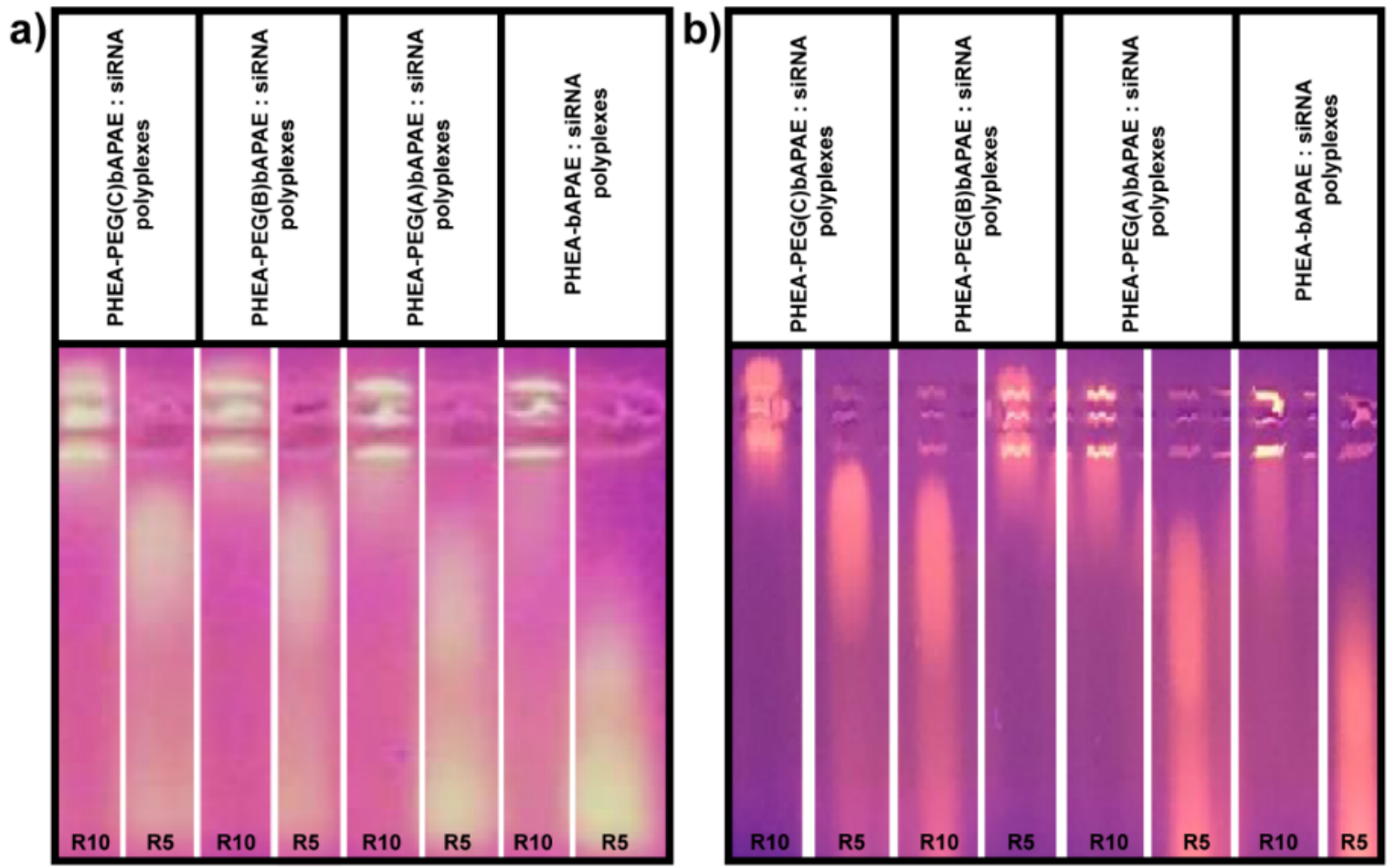

Figure 12. Gel electrophoresis in the presence of mucin, after (a) $2 \mathrm{~h}$ and (b) $5 \mathrm{~h}$ of incubation, at $\mathrm{R}=5$ and 10.

As showed in Figure 12, all the polyplexes give a polyanionic exchange between siRNA and mucin, so that a higher weight ratio $(R=10)$ needs to stop the electrophoretic run of siRNA respect to that request in the absence of mucin, as reported in Figure 10.

Therefore, the mucin competes with the siRNA for the electrostatic interactions with the copolymer, so that a higher amount of copolymer is request to form polyplexes. In order to obtain more informations regarding the specific interaction of each copolymer forming the polyplex with mucin, a turbidimetric assay was carried out at three different $R$ values $(3,5$, and 10$)$ as a function of incubation time, considering that if polyplexes-mucin interactions occur, it involves a reduction of transmittance of the dispersion. Data are reported in Figure 13a-d, as trasmittance \% as a function of incubation time.

As can be seen, polyplexes obtained with PHEA-g-bAPAE shown a muco-adhesive behaviour, especially as the weight ratio value $R$ increases. The dependence from $R$ is also showed by the polyplexes obtained with the pegylated copolymers. On the other hand, for the pegylated polyplexes, the interaction capability with mucin decreases as the amount of PEG in the polymeric backbone increases to all selected $R$ values. The polyplexes obtained with PHEA-g-PEG(C)-g-bAPAE seems to be not susceptible to the presence of mucin, showing high trasmittance values at all the incubation times also at higher concentration (corresponding to $R=10$ ). The latter also represents the minimum weight ratio to avoid the polyanionic exchange of complexed siRNA with mucin, thus showing adequate behavior to be used as an effective vector for siRNA. 

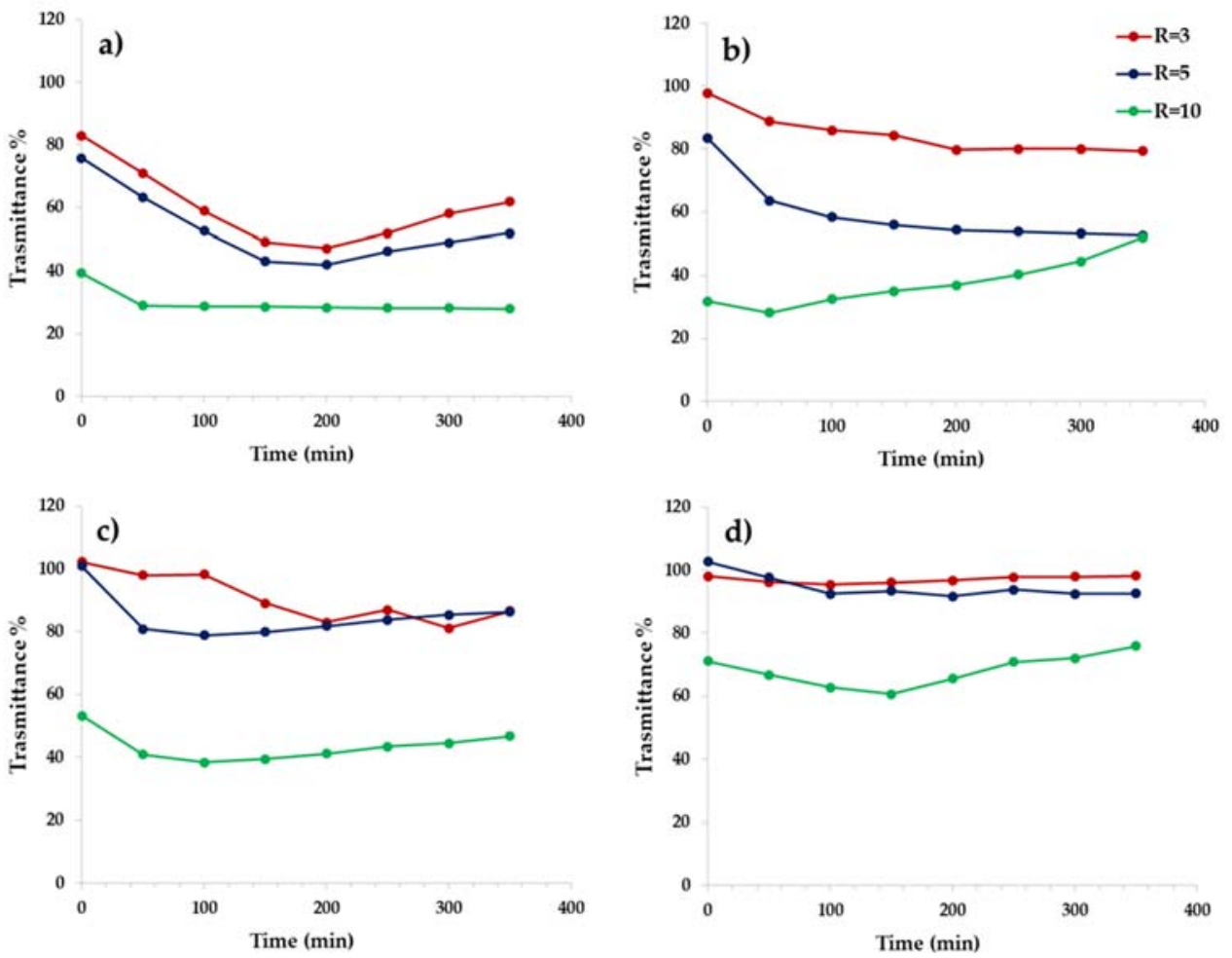

Figure 13. Turbidimetric analysis. Trasmittance at $500 \mathrm{~nm}$ of a dispersion containing mucin in the presence of polyplexes between siRNA and: (a) PHEA- $g$-bAPAE; (b) PHEA- $g$-PEG(A)- $g$-bAPAE; (c) PHEA-g-PEG(B)-g-bAPAE; (d) PHEA- $g$-PEG(C)-g-bAPAE graft copolymers, at R equal to 3, 5, and 10.

\subsection{Gene Silencing Assay}

Once demonstrated that these polyplexes are stable the capability to act as an effective carrier for siRNA and to allow the cellular internalization was evaluated. In particular, the gene silencing capacity of obtained polyplexes was evaluated by in vitro ELISA test upon 16-HBE cells. Cells were treated with: a) Naked siRNA and b) polyplexes obtained with each copolymer and at three different $\mathrm{R}$, and then exposed to an inflammatory agent, such as LPS. Relative IL-4 production (percentage) was expressed as (Abs treated cells/Abs positive control cells) $\times 100$. Obtained values are reported in Figure 14.

Obtained results show that cell incubated with naked siRNA produce an IL amount non significantly different from that obtained with control cells. When cells are incubated in the presence of polyplexes, there is a reduction in the expression of IL-4 in all cases, even if not in a massive way. However, this experiment showed that polymeric carrier has a fundamental role in cellular transport and uptake of siRNA. Another important result is given by the fact that presence of PEG does not seem to hinder the cellular uptake of polyplexes, as found for other pegylated non viral polymeric vectors for siRNA [7]. However, at $R=10$, among the pegylated polyplexes, the capability to allow the intracellular delivery of siRNA is inversally related to the PEG amount in a significant way, while at the other R no significant differences are observed. 


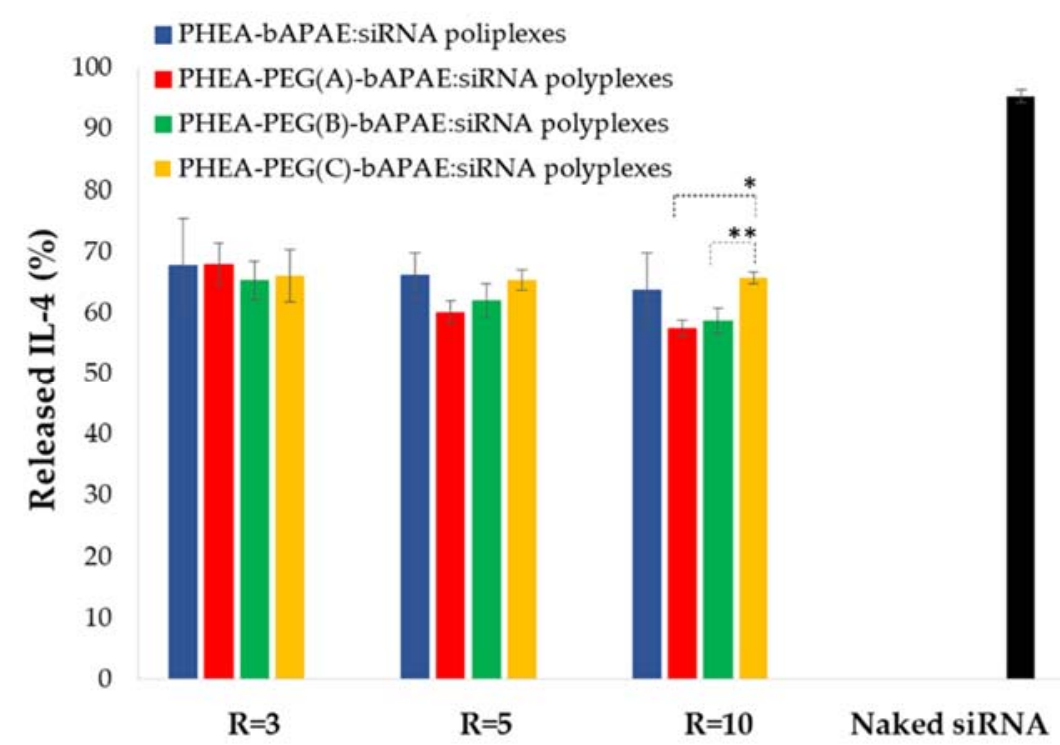

Figure 14. IL-4 (\%) released by 16-HBE cells after incubation with polyplexes or with naked siRNA for $48 \mathrm{hrs}$, compared to positive control. $\left({ }^{*} p<0.01 ;{ }^{* *} p<0.001\right)$.

\section{Conclusions}

The discovery of new targets for the treatment of pathologies has gone hand in hand with the need for new carriers able to allow an adequate release to the site of action and to obtain the maximum effectiveness on the treated cells. Gene therapy using non-viral vectors is very popular today, especially because it is safer than using viral vectors, although less efficient. Therefore, the realization of synthetic polymeric carriers has allowed us to design a polymer and its realization by adding perfectly functional components to its structure.

In this work, a protonable copolymer was designed for the production of polyplexes with a siRNA for the treatment of asthma. It was obtained by using PHEA as starting polymer, that is highly functionalisable, and as molecule to be conjugated in a side chain to complex siRNA, we have chosen a oligoamin bAPAE. The latter was bonded in a suitable quantity by means of a easy to reproduce reaction. Since it was thought to administer the polyplex directly to the lung, the carrier has been appropriately functionalized with variable amounts of PEG, since it is already known that the latter molecule is able to modulate the hydrophilicity, shield the charge of the material, and thus confer the ability to penetrate through a mucus layer.

All the obtained copolymers, pegylated or not, were able to complex the selected siRNA at quite low values of weight ratios, giving nanosized complexes with a tendence to the aggregation invertially proportional to the pegylation degree. These polyplexes seem to be destabilized by mucin, that gives polyanionic exchange with siRNA by direct electrostatic interactions of each copolymer with mucin. However, these interactions decrease as a function of the amount of linked PEG, resulting very low for the highest pegylated polyplexes based on the PHEA-g-PEG(C)-g-bAPAE copolymer. Moreover, the complexation of siRNA with all the synthesized copolymers significantly increases the ability of complexed siRNA to be internalized by the $16 \mathrm{HBE}$ cells. Therefore, the PHEA-g-PEG(C)-g-bAPAE copolymer possesses interesting potential as a pulmonary siRNA carrier, being not interacting with mucins and able to give neutral polyplexes with quite static dimensions in a wide range of weight ratio.

Furthermore, the performance of PHEA-g-PEG(C)-g-bAPAE copolymer, as siRNA delivery system, is going to be improved by grafting on the copolymer structure other functional moieties such as cell penetrating peptides, able to improve cell internalization of the siRNA/copolymer polyplexes and/or cross-linking agents able to increase polyplexe stability in biological environment. 
Supplementary Materials: The following are available online at http://www.mdpi.com/1999-4923/12/2/89/s1, Figure S1: SEC chromatograms of: a) PHEA-g-bAPAE (black), PHEA-g-PEG(A)-g-bAPAE (blue), PHEA-g-PEG(B)-g-bAPAE (red), PHEA-g-PEG(c)-g-bAPAE (green); b) PHEA-g-PEG(A) (black), PHEA-g-PEG(B) (red), PHEA-g-PEG(C) (green).

Author Contributions: G.C. and G.G. conceived and designed the experiments and organized the manuscript writing. S.E.D. and E.F.C. performed the experiments, analyzed the data and wrote the paper. N.M. analyzed and fitted titration data. All authors have read and agreed to the published version of the manuscript.

Funding: This research received no external funding.

Acknowledgments: Authors thank ATeN Center of University of Palermo-Laboratory of Preparation and Analysis of Biomaterials, for the support in the Size Exclusion Chromatography analysis.

Conflicts of Interest: The authors declare no conflict of interest.

\section{References}

1. Shakshuki, A.; Agu, R.U. Improving the Efficiency of Respiratory Drug Delivery: A Review of Current Treatment Trends and Future Strategies for Asthma and Chronic Obstructive Pulmonary Disease. Pulm. Ther. 2017, 3, 267-281. [CrossRef] [PubMed]

2. Anderson, S.D. Repurposing drugs as inhaled therapies in asthma. Adv. Drug Deliv. Rev. 2018, 133, $19-33$. [CrossRef] [PubMed]

3. Kanemitsu, Y.; Matsumoto, H.; Izuhara, K.; Tohda, Y.; Kita, H.; Horiguchi, T.; Kuwabara, K.; Tomii, K.; Otsuka, K.; Fujimura, M.; et al. Increased periostin associates with greater airflow limitation in patients receiving inhaled corticosteroids. J. Allergy Clin. Immunol. 2013, 132, 305-312. [CrossRef] [PubMed]

4. Miyake, T.; Miyake, T.; Sakaguchi, M.; Nankai, H.; Nakazawa, T.; Morishita, R. Prevention of Asthma Exacerbation in a Mouse Model by Simultaneous Inhibition of NF- $\mathrm{B}$ and STAT6 Activation Using a Chimeric Decoy Strategy. Mol. Ther. Nucleic Acids 2018, 10, 159-169. [CrossRef]

5. Cho, S.H.; Jo, A.; Casale, T.; Jeong, S.J.; Hong, S.J.; Cho, J.K.; Holbrook, J.T.; Kumar, R.; Smith, L.J. Soy isoflavones reduce asthma exacerbation in asthmatic patients with high PAI-1-producing genotypes. J. Allergy Clin. Immunol. 2019, 144, 109-117. [CrossRef]

6. Tabeling, C.; Herbert, J.; Hocke, A.C.; Lamb, D.J.; Wollin, S.L.; Erb, K.J.; Boiarina, E.; Movassagh, H.; Scheffel, J.; Doehn, J.M.; et al. Spleen tyrosine kinase inhibition blocks airway constriction and protects from Th2-induced airway inflammation and remodeling. Allergy Eur. J. Allergy Clin. Immunol. 2017, 72, 1061-1072. [CrossRef]

7. Cavallaro, G.; Sardo, C.; Craparo, E.F.; Porsio, B.; Giammona, G. Polymeric nanoparticles for siRNA delivery: Production and applications. Int. J. Pharm. 2017, 525, 313-333. [CrossRef]

8. Park, J.; Park, J.; Pei, Y.; Xu, J.; Yeo, Y. Pharmacokinetics and biodistribution of recently-developed siRNA nanomedicines. Adv. Drug Deliv. Rev. 2016, 104, 93-109. [CrossRef]

9. David, S.; Pitard, B.; Benoît, J.P.; Passirani, C. Non-viral nanosystems for systemic siRNA delivery. Pharmacol. Res. 2010, 62, 100-114. [CrossRef]

10. Cooper, B.M.; Putnam, D. Polymers for siRNA delivery: A Critical Assessment of Current Technology Prospects for Clinical Application. ACS Biomater. Sci. Eng. 2016, 2, 1837-1850. [CrossRef]

11. Giammona, G.; Carlisi, B.; Palazzo, S. Reaction of $\alpha, \beta$-poly(N-hydroxyethyl)-DL-aspartamide with derivatives of carboxylic acids. J. Polym. Sci. Part A Polym. Chem. 1987, 25, 2813-2818. [CrossRef]

12. Cavallaro, G.; Farra, R.; Craparo, E.F.; Sardo, C.; Porsio, B.; Giammona, G.; Perrone, F.; Grassi, M.; Pozzato, G.; Grassi, G.; et al. Galactosylated polyaspartamide copolymers for siRNA targeted delivery to hepatocellular carcinoma cells. Int. J. Pharm. 2017, 525, 397-406. [CrossRef] [PubMed]

13. Gioia, S.D.; Sardo, C.; Belgiovine, G.; Triolo, D.; d'Apolito, M.; Castellani, S.; Carbone, A.; Giardino, I.; Giammona, G.; Cavallaro, G.; et al. Cationic polyaspartamide-based nanocomplexes mediate siRNA entry and down-regulation of the pro-inflammatory mediator high mobility group box 1 in airway epithelial cells. Int. J. Pharm. 2015, 491, 359-366. [CrossRef] [PubMed]

14. Craparo, E.F.; Cavallaro, G.; Bondì, M.L.; Giammona, G. Preparation of polymeric nanoparticles by photo-crosslinking of an acryloylated polyaspartamide in w/o microemulsion. Macromol. Chem. Phys. 2004, 205, 1955-1964. [CrossRef] 
15. Pitarresi, G.; Palumbo, F.S.; Calabrese, R.; Craparo, E.F.; Giammona, G. Crosslinked hyaluronan with a protein-like polymer: Novel bioresorbable films for biomedical applications. J. Biomed. Mater. Res.-Part A 2008, 84, 413-424. [CrossRef]

16. Craparo, E.F.; Teresi, G.; Licciardi, M.; Bondí, M.L.; Cavallaro, G. Novel composed galactosylated nanodevices containing a ribavirin prodrug as hepatic cell-targeted carriers for HCV treatment. J. Biomed. Nanotechnol. 2013, 9, 1107-1122. [CrossRef]

17. Licciardi, M.; Di Stefano, M.; Craparo, E.F.; Amato, G.; Fontana, G.; Cavallaro, G.; Giammona, G. PHEA-graft-polybutylmethacrylate copolymer microparticles for delivery of hydrophobic drugs. Int. J. Pharm. 2012, 433. [CrossRef]

18. Suma, T.; Miyata, K.; Ishii, T.; Uchida, S.; Uchida, H.; Itaka, K.; Nishiyama, N.; Kataoka, K. Enhanced stability and gene silencing ability of siRNA-loaded polyion complexes formulated from polyaspartamide derivatives with a repetitive array of amino groups in the side chain. Biomaterials 2012, 33, 2770-2779. [CrossRef]

19. Darcan-Nicolaisen, Y.; Meinicke, H.; Fels, G.; Hegend, O.; Haberland, A.; Kühl, A.; Loddenkemper, C.; Witzenrath, M.; Kube, S.; Henke, W.; et al. Small Interfering RNA against Transcription Factor STAT6 Inhibits Allergic Airway Inflammation and Hyperreactivity in Mice. J. Immunol. 2009, 182, 7501-7508. [CrossRef]

20. Rippmann, J.F.; Schnapp, A.; Weith, A.; Hobbie, S. Gene silencing with STAT6 specific siRNAs blocks eotaxin release in IL-4/TNF $\alpha$ stimulated human epithelial cells. FEBS Lett. 2005, 579, 173-178. [CrossRef]

21. Lomonossoff, G. Modified Plant Virus Particles and Uses Therefor. U.S. Patent US20120015899A1, 19 January 2012.

22. Wu, Z.; Liu, J.; Hu, S.; Zhu, Y.; Li, S. Serine/threonine kinase 35, a target gene of stat3, regulates the proliferation and apoptosis of osteosarcoma cells. Cell. Physiol. Biochem. 2018, 45, 808-818. [CrossRef] [PubMed]

23. Craparo, E.F.; Porsio, B.; Sardo, C.; Giammona, G.; Cavallaro, G. Pegylated PolyaspartamidePolylactide-Based Nanoparticles Penetrating Cystic Fibrosis Artificial Mucus. Biomacromolecules 2016, 17, 767-777. [CrossRef]

24. Craparo, E.F.; Porsio, B.; Mauro, N.; Giammona, G.; Cavallaro, G. Polyaspartamide-Polylactide Graft Copolymers with Tunable Properties for the Realization of Fluorescent Nanoparticles for Imaging. Macromol. Rapid Commun. 2015, 36, 1409-1415. [CrossRef]

25. Montana, G.; Bondì, M.L.; Carrotta, R.; Picone, P.; Craparo, E.F.; San Biagio, P.L.; Giammona, G.; Di Carlo, M. Employment of cationic solid-lipid nanoparticles as RNA carriers. Bioconjug. Chem. 2007, 18, 302-308. [CrossRef] [PubMed]

26. Craparo, E.F.; Triolo, D.; Pitarresi, G.; Giammona, G.; Cavallaro, G. Galactosylated micelles for a ribavirin prodrug targeting to hepatocytes. Biomacromolecules 2013, 14, 1838-1849. [CrossRef] [PubMed]

27. Behr, J.P. The proton sponge: A trick to enter cells the viruses did not exploit. Chimia 1997, 51, 34-36.

28. Patel, S.; Kim, J.; Herrera, M.; Mukherjee, A.; Kabanov, A.V.; Sahay, G. Brief update on endocytosis of nanomedicines. Adv. Drug Deliv. Rev. 2019, 144, 90-111. [CrossRef]

29. Mauro, N.; Fiorica, C.; Varvarà, P.; Di Prima, G.; Giammona, G. A facile way to build up branched high functional polyaminoacids with tunable physicochemical and biological properties. Eur. Polym. J. 2016, 77, 124-138. [CrossRef]

30. Ferruti, P.; Mauro, N.; Falciola, L.; Pifferi, V.; Bartoli, C.; Gazzarri, M.; Chiellini, F.; Ranucci, E. Amphoteric, prevailingly cationic L-arginine polymers of poly(amidoamino acid) structure: Synthesis, acid/base properties and preliminary cytocompatibility and cell-permeating characterizations. Macromol. Biosci. 2014, 14, 390-400. [CrossRef]

31. De Levie, R. How to Use Excel ${ }^{\circledR}$ in Analytical Chemistry and in General Scientific Data Analysis; Cambridge University Press: Cambridge, UK, 2001; ISBN 9780511808265.

32. Scialabba, C.; Sciortino, A.; Messina, F.; Buscarino, G.; Cannas, M.; Roscigno, G.; Condorelli, G.; Cavallaro, G.; Giammona, G.; Mauro, N. Highly Homogeneous Biotinylated Carbon Nanodots: Red-Emitting Nanoheaters as Theranostic Agents toward Precision Cancer Medicine. ACS Appl. Mater. Interfaces 2019, 11, 19854-19866. [CrossRef]

(C) 2020 by the authors. Licensee MDPI, Basel, Switzerland. This article is an open access article distributed under the terms and conditions of the Creative Commons Attribution (CC BY) license (http://creativecommons.org/licenses/by/4.0/). 